\title{
Metabolism and Biological Activities of 4-Methyl-Sterols
}

\author{
Sylvain Darnet ${ }^{1, *(D)}$ and Hubert Schaller $2, *$ (D) \\ CVACBA, Instituto de Ciências Biológicas, Universidade Federal do Pará, Belém, PA 66075-750, Brazil \\ 2 Plant Isoprenoid Biology (PIB) team, Institut de Biologie Moléculaire des Plantes du CNRS, \\ Université de Strasbourg, Strasbourg 67084, France \\ * Correspondence: sylvain@ufpa.br (S.D.); hubert.schaller@ibmp-cnrs.unistra.fr (H.S.); \\ Tel.: +55-91-3201-7456 (S.D.); +33-3-6715-5265 (H.S.)
}

Academic Editor: Wenxu Zhou

Received: 24 December 2018; Accepted: 23 January 2019; Published: 27 January 2019

\begin{abstract}
Dimethylsterols and 4-methylsterols are sterol biosynthetic intermediates (C4-SBIs) acting as precursors of cholesterol, ergosterol, and phytosterols. Their accumulation caused by genetic lesions or biochemical inhibition causes severe cellular and developmental phenotypes in all organisms. Functional evidence supports their role as meiosis activators or as signaling molecules in mammals or plants. Oxygenated C4-SBIs like 4-carboxysterols act in major biological processes like auxin signaling in plants and immune system development in mammals. It is the purpose of this article to point out important milestones and significant advances in the understanding of the biogenesis and biological activities of C4-SBIs.
\end{abstract}

Keywords: sterol; C4-demethylation complex (C4DMC); 4-methylsterol; hormone; steroid; development; genetic disease

\section{An Introduction to 4-Methylsterols}

Post-squalene sterol biosynthesis consists in the enzymatic conversion of $\mathrm{C}_{30} \mathrm{H}_{50} \mathrm{O}$ steroidal triterpene precursors such as lanosterol or cycloartenol into pathway end-products among which the most popular are cholesterol, ergosterol, poriferasterol, sitosterol, and many others distributed among eukaryotes. Several dozens of sterol structures may be detected and identified in given organisms or tissues [1-5]. Biosynthetic relationships between all these sterol structures have been extensively documented [6-8]. Sterol structural differences between eukaryotic kingdoms involve the number of exocyclic carbon atoms at position $\mathrm{C} 24$ and unsaturations in the B cycle of the cholestane backbone (Figure $1 \mathrm{~A}, \mathrm{~B}$ ). Cholesterol is a $\Delta^{5}$-sterol bearing the eight carbon side chain at position $\mathrm{C} 17$, which is a structural feature resulting from the cyclization of 2,3-oxidosqualene $\left(\mathrm{C}_{30} \mathrm{H}_{50} \mathrm{O}\right)$ into a protosteryl cationic reaction intermediate and then into lanosterol or cycloartenol [9]. In plants, campesterol and sitosterol are $\Delta^{5}$-sterols with one and two methyl groups at position $\mathrm{C} 24$, respectively. In yeast, ergosterol is a $\Delta^{5,7}$-sterol with one extra methyl group at C24. Sterol pathways are markedly different between eukaryotes depending on the cyclization of 2,3-oxidosqualene into lanosterol in fungi and mammals or cycloartenol in some protists and plants (Figure 2). In fact, this dichotomy generates the particular series of $9 \beta, 19$-cyclopropylsterols derived from cycloartenol, the biosynthetic and functional features of which have been discussed [6-8].

The enzymatic conversion of lanosterol or cycloartenol into pathway end-products (cholesterol, ergosterol, and phytosterols) implies crucial demethylation steps at C14 and C4 positions. Here again, substrates of these reactions in the eukaryotic kingdom differ. Mammals and fungi perform two consecutive C4-demethylations of 30-nor-lanosterol occurring right after the mandatory C14-demethylation of lanosterol, whereas plants carry out two distinct and nonconsecutive 
C4-demethylations, the first one applying to a 4,4,14-trimethylsterol and the second one to a 4,14-dimethylsterol or a 4-methylsterol (Figure 2).

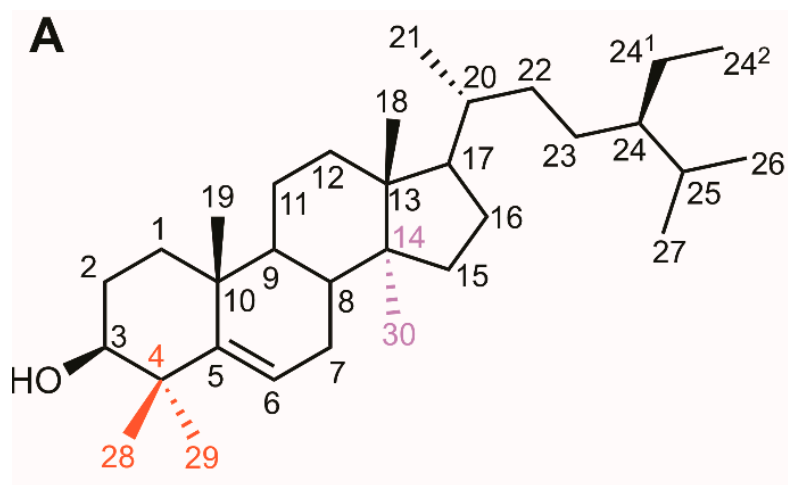

B
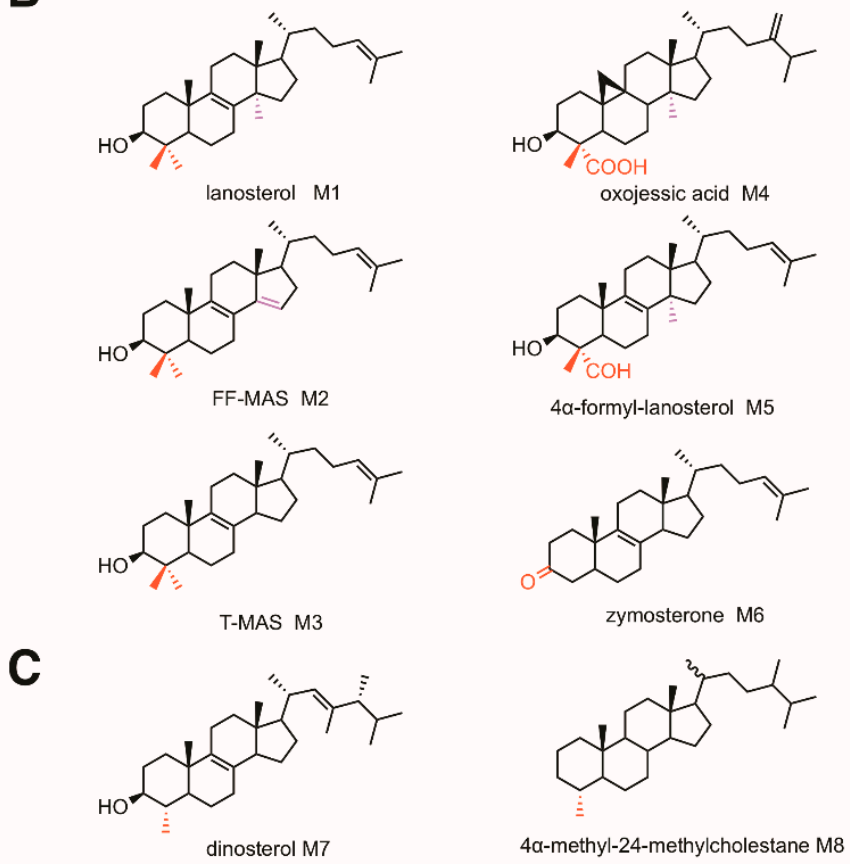

Figure 1. Sterol and 4-methylsterol structures. (A) carbon numbering. (B) some compounds described in this article. (C) dinosterol and a sterane, a biogeological marker.

Both sterol demethylations at $\mathrm{C} 4$ and $\mathrm{C} 14$ require molecular oxygen for the oxidative cleavage of carbon-carbon bonds, but enzymes at play are different. Demethylation at C14 is catalyzed by a $14 \alpha$-methylsterol-14 $\alpha$-methyl-demethylase, which is a cytochrome P450-dependent mono-oxygenase also known as CYP51 in mammals [10-12], in yeast [13] and in plants [14-16]. A $\Delta^{14}$-sterol-14-reductase catalyzes the reduction of the resulting $\Delta^{8,14}$-diene (Figure 2 and Figure S1A). This enzyme is encoded by a single gene in plants and yeast $[17,18]$, while in human two distinct genes were characterized $[19,20]$. In the same organisms, the demethylation at C4 leads to the production of $4 \alpha$-carboxysterols by an oxygen-dependent process followed by an oxygen-independent C-C cleavage that generates 3-ketosterols (Figure S1B) [21]. It is now established that sterol-C4-demethylation implies the consecutive action of three enzymes: a sterol- $4 \alpha$-methyl oxidase (SMO), a $3 \beta$-hydroxysteroid dehydrogenase/C4-decarboxylase (C4D), and a sterone ketoreductase (SKR) [22] (Figure 2 and Figure S1B). A protein called ERG28 was shown to tether all three enzymes as a complex in the endoplasmic reticulum [23]. 

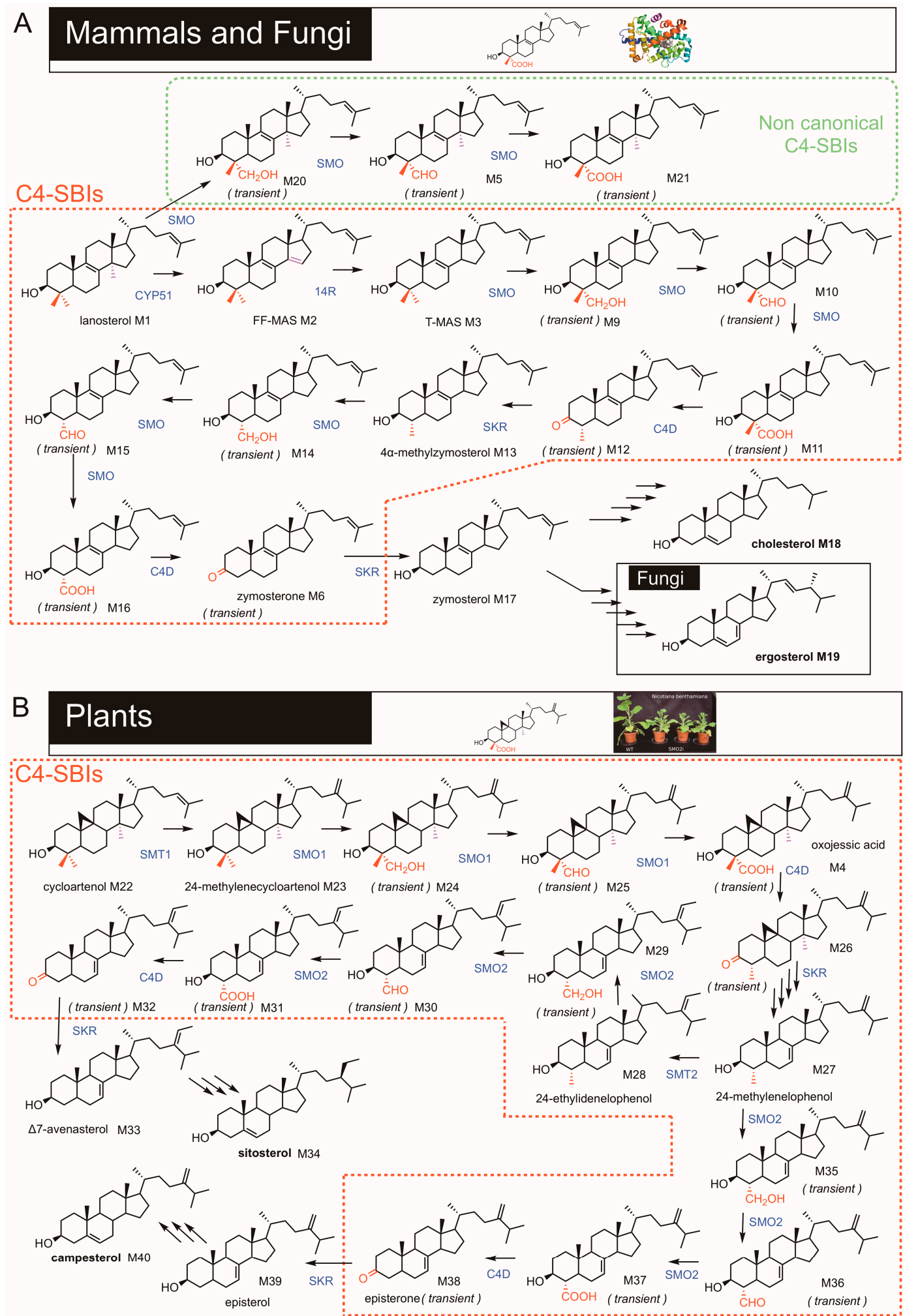

Figure 2. C4-demethylation pathways in mammals and fungi, and plants. Sterol nomenclature is given in Table 1. (A) pathways in mammals and fungi; (B) pathway in plants; C4-demethylation in eukaryotes: SMO, sterol- $4 \alpha$-methyl-oxidase; C4D, 3 $\beta$-hydroxysteroid dehydrogenases/C-4 decarboxylase; SKR, sterone ketoreductase, C14-demethylation: CYP51, lanosterol-C14 demethylase. SMT, sterol methyltransferase; 14R, sterol-14-reductase. Each arrow represents an enzymatic step. Graphical insets are from references ([24] in top and [25] bottom panels). 
A prominent category of sterol biosynthetic intermediates is 4-methylsterols (including 4,4-dimethylsterols) hereafter collectively named C4-Sterol Biosynthetic Intermediates (C4-SBIs). These molecules with one or two methyl groups at position $\mathrm{C} 4$ are precursors of 4-desmethylsterols, like cholesterol in animals, ergosterol in yeast, poriferasterol in some algae, and phytosterols in plants, as stated above.

The C4-SBIs in mammals and fungi are compounds which follow each other in a biosynthetic segment joining lanosterol to zymosterol. In plants, the pathway is different. The C4-SBIs include compounds which succeed each other in biosynthetic segments joining cycloartenol to episterol or $\Delta^{7}$-avenasterol, two 24-alkyl-4-desmethylsterols (Figure 2). C4-SBIs are amphiphilic molecules with a rigid structure just like 4-desmethylsterols. Four rings (A, B, C, D) form a quasi-planar tetracyclic nucleus, with a hydroxy or keto group at the $\mathrm{C} 3$ position, one or two methyl groups at the $\mathrm{C} 4$ position, methyl groups at the $\mathrm{C} 10$ and $\mathrm{C} 13$ positions, and an aliphatic side chain of 8 to 10 carbon atoms at C17 (Figure 1A). C4-SBIs display a variety of structural motifs: unsaturations at different positions of the B ring $\left(\Delta^{7(8)}\right.$ or $\Delta^{8(9)}$ or $\Delta^{9(11)}$ or $\left.\Delta^{8,14}\right)$, a cyclopropanic cycle on the B ring, a methyl group at $\mathrm{C} 14$ and a methyl (or methylene) or ethyl (or ethylidene) at C24 on the side chain (Figure 1B). C4-SBIs are generally in low abundance contrasting with cellular amounts of pathway end-products. There are however organisms that contain substantial amounts of 4-methylsterols such as dinosterol implied in cold adaptation (Figure 1C) in dinoflagellates [26], or 4,4-dimethylsterols and 4-methyl- $\Delta^{7}$-sterols in the prokaryote Methyloccocus capsulatus [27]. Because dinosterol is restricted to dinoflagellates its sterane derivatives are used as biogeological markers of Phanerozoic sediments [28]. Alternatively, $4 \alpha$-methyl-24-ethylcholestane may derive from C4-methylsterols from other yet unrecognized Proterozoic eukaryotic organisms that used C4-SBIs as membrane components (Figure 1C) [29]. The capacity of C4-SBIs like for instance cycloartenol to act as an efficient membrane structural component in primitive organisms has been discussed [30]. In this respect, a yeast mutant erg7 deficient in lanosterol synthase (ergosterol-auxotrophic) could, however, live on C4-SBIs such as cycloartenol upon expression of a cycloartenol synthase [31,32].

C4-SBIs may be classified from an operational point of view according to amounts detected in an organism or tissue, as major C4-SBIs and transient C4-SBIs. Major C4-SBIs are present in few percents of total sterols, about several $\mu \mathrm{g} \cdot \mathrm{g}^{-1}$ dry weight, like for instance lanosterol in yeast, cycloartenol in Artocarpus integrifolia [33], or cycloeucalenol and obtusifoliol in plant tissues [34], and 24-ethylidenelophenol in Hordeum vulgare [35]. Transient C4-SBIs are intermediates of the sterol-C4-demethylation process catalyzed by a complex of enzymes (C4-DeMethylation Complex, C4DMC) and are generally not detected in sterol profiles under normal physiological conditions. These compounds are 4-hydroxymethylsterols, 4-formylsterols, 4-carboxysterols, canonical and non-canonical C4-SBIs and 3-ketosterols (Figure 2A).

The effectiveness of 4,4-dimethylsterols such as lanosterol (compared to cholesterol) in regulating membrane fluidity and supporting cellular functions in Mycobacterium capricolum was assessed by measuring microviscosity of membranes and establishing their capacity to promote prototrophic growth. Membranes of M. capricolum grown on medium containing 4,4-dimethylsterols or 4-methylsterols have microviscosity values found in between those of lanosterol (low value) and cholesterol (high value). These experiments demonstrated that the successive carbon removals at C14 of lanosterol then at C4 of 4,4-dimethylzymosterol and 4-methylzymosterol en route to cholesterol biosynthesis (Figure 2) progressively shaped a sterol molecule in order to sustain optimal cell growth [36]. This is in agreement with the identification of 4-methysterols in ancestral organisms $[29,37,38]$.

Physiological roles of C4-SBIs have been described. Lanosterol in the brain is associated with a neuroprotective effect in Parkinson's disease [39]. An increase of oligodendrocyte formation and remyelination was observed in the presence of C4-SBIs [40]. In mammal reproductive biology, Meiosis Activating Sterols (MAS) are major C4-SBIs found in follicular fluid (FF-MAS) and testicular tissue (T-MAS) (Figure 1B) [41-43]. FF-MAS are crucial for proper meiosis and for oocyte maturation 
in vitro [43,44]. Sterol biosynthetic flux analyzed in mice revealed a high rate of FF-MAS and T-MAS synthesis that defines cell-type specific pathways and also raised new hypothesis about the fate of T-MAS in testes (forming zymosterol, another sterol, a steroid hormone, or an excreted product) [45]. Synthetic FF-MAS and T-MAS were developed for further biological studies [46,47]. Human genetic diseases known as sterolosis are characterized by a dramatic accumulation of sterol intermediates including the immediate cholesterol precursors lathosterol and desmosterol (their accumulation causing lathosterolosis and desmosterolosis, respectively) but also of C4-SBIs causing severe alterations in development at early (embryo malformation) or later stages (skin anatomical changes) [48-50]. In Caenorhabditis elegans, 4-methylsterols are generated from cholesterol by an unusual C4-methylation enzyme that is only found in worms (Figure 3) [51]. In plants and mammals, transient C4-SBIs bearing a 4-formyl or 4-carboxy group were functionally linked to critical biological processes: the accumulation of $4 \alpha$-carboxy- $4 \beta$-methyl-24-methylenecycloartanol (oxojessic acid, Figure 1B) was shown to hamper proper auxin signaling in the model plant Arabidopsis thaliana [52], and $4 \alpha$-formyl-lanosterol (Figure 1B) was described as a physiological ligand of ROR $\gamma$, a protein that regulates lymphoid cell development [25].

\section{Some Crucial Milestones in Deciphering the Sterol-Demethylation Process and Functions of C4-SBIs in Mammals}

In mammals, the first demethylation step occurs at C14 position (Figure 2). This is achieved by a lanosterol-14 $\alpha$-methyl-demethylase (CYP51) [10-12] which removes the $14 \alpha$-methyl group as formic acid resulting in a $\Delta^{8,14}$-diene product (Figure S1A) [53]. This reaction requires NADPH and generates a $14 \alpha$-formyloxysterol reaction intermediate on which CYP51 acts as a lyase in cleaving the C-C bond (Figure 2 and Figure S1A). The CYP51A1 gene was identified in human and characterized by heterologous expression in bacteria [54]. The subsequent $\Delta^{8,14}$-sterol- $\Delta^{14}$-reduction (Figure 2 and Figure S1A) has been the focus of considerable research effort over the last decade. In human, two different genes encode products that bear sterol-14-reductase activity, namely, LBR and TM7SF2 genes $[19,20]$. The LBR protein is bifunctional; it has a lamin B receptor (LBR) and sterol-14-reductase domains and is mainly acting on the cholesterol biosynthetic flux. The TM7SF2 protein, although exhibiting sterol-14-reductase activity, has not a well-defined function in cholesterol biosynthesis. The intracellular localization of these two proteins is different: LBR is addressed to the nuclear envelope, it bears a chromatin-binding $\mathrm{N}$-terminus; TM7SF2 resides in the endoplasmic reticulum membranes [55-58].

The removal of C4 methyl groups as carbon dioxide during the conversion of lanosterol into cholesterol was shown years ago, suggesting that the demethylation reaction implied an $\beta$ keto acid intermediate [59]. Another experimental evidence was provided by Bloch and co-workers who showed that the aerobic incubation of labeled 4-hydroxy-methylene-cholest-7-en-3-one in a rat liver homogenate resulted in a marked release of carbon dioxide from the reaction medium [60,61]. The subsequent isolation of 3-keto and $4 \alpha$-acid reaction products supported the proposed mechanistic hypothesis for the $\mathrm{C} 4$ demethylation reaction: in rat liver microsomes, the incubation of ${ }^{14} \mathrm{C}$-labeled 4,4-dimethyl-5 $\alpha$-cholest-7-en-3-ol in the absence of NADPH led to the production of labeled carbon dioxide and mono-methylated products 3-keto- $5 \alpha$-cholest-7-en-3-one and 4-methyl-5 $\alpha$-cholest-7-en-3-one [62]. Similarly, the incubation of a 4-methylsterol produced carbon dioxide and a demethylated ketone at the $\mathrm{C} 4$ position [63]. In the presence of NADPH, these ketones are reduced to the corresponding $3 \alpha$-alcohol by a 3-ketosteroid reductase [64]. The early stages of cholesterol biosynthesis studies and especially the identification of associated enzyme activities raised the question of the formation of the C4-carboxyl group preceding the carbon-carbon cleavage and loss of carbon dioxide, this based on a partial purification of an NAD+ decarboxylase $[65,66]$. Gaylor and co-workers showed that the oxidation of the methyl group at $\mathrm{C} 4$ to the corresponding acid required molecular oxygen and $\mathrm{NADH}$ and was sensitive to cyanide $[67,68]$. Also, the inhibition of C4-demethylation by snake venom phospholipases suggested the involvement of an NADH-dependent 
cytochrome b5 reducing system [63]. Finally, in recent decades, the complete set of genes coding the enzymes implied in the sterol-C4-demethylation step of mammalian cholesterol biosynthesis was identified particularly in deciphering some human genetic diseases; enzymes were thereafter biochemically characterized in heterologous systems [50,69,70]. The non-enzymatic protein ERG28 necessary for the activity of the C4DMC was lastly identified in human based on its yeast orthologs [71].

Functional studies of C4-SBIs have underlined critical biological properties of lanosterol. Lanosterol and oxysterols affect human cataracts [72]. A functional screening of molecules that bind alpha-crystallins (cryAA and cryAB) in vitro and reversed their aggregation identified 5 -cholesten-3 $\beta, 25$-diol as an active compound, based on improved lens transparency in cataract models [73]. In another study, the direct relationship between congenital cataracts and lanosterol was shown by the elucidation of two causal mutations in the gene encoding lanosterol synthase [74]. The role of lanosterol in arresting cataract development was furthermore ascertained by its positive effect on protein disaggregation and the increase of lens transparency, both in vitro and in vivo, in rabbit and dog [74]. Further studies provided additional evidence to establish lanosterol firmly as an anti-cataract drug [74-77]. Although the molecular mechanism is not described, Quinlan [72] et al. have suggested that C4-SBIs, like lanosterol, could interact with small heat shock proteins, which function as sterol sensors regulating cellular and developmental processes. Lanosterol also has a tremendous impact on innate immunity [78]. The activation of Toll-Like Receptor 4 (TLR4) in macrophages is responsible for the transcriptional repression of CYP51, resulting in the accumulation of lanosterol. Such an accumulation of lanosterol, by genetic or by chemical inhibition, has a regulatory action on the immune response, membrane fluidity, ROS production and potentialize phagocytosis [78]. Considering cellular sterol homeostasis, lanosterol and 24,25-dihydrolanosterol are known to interact with the Insig signaling pathway that promotes the degradation of HMGR, a key enzyme of the mevalonate pathway [79]. Lanosterol and 24,25-dihydrolanosterol may also act as an oxygen sensor: in hypoxic conditions, the $\mathrm{C} 14$ and $\mathrm{C} 4$ demethylations rate is reduced, and consequently promote HMGR degradation, lowering thus the cholesterol biosynthetic flux [80].

The critical importance of C4-SBIs that are the reaction products of LBR and TM7SF2, two proteins bearing sterol-14-reductase domains, has emerged recently $[55,56,58]$. LBR and TM7SF2 act as regulators of TNF $\alpha$ expression in human, and skin papilloma development in mice [58,81-85]. The Greenberg skeletal dysplasia, the Renolds syndrome and Pelger-Huët anomaly are severe genetic diseases due to mutations in the LBR gene, causing a reduction in sterol-14-reductase activity and therefore promoting the accumulation FF-MAS, the substrate of the enzyme [86-89]. The molecular mechanism that is most probably at play in these diseases may be very close to an enhanced lipogenesis and the inhibition of cell proliferation mediated by the liver $X$ receptor alpha $(\mathrm{LXR} \alpha)$, to which binds the C4-SBI molecule FF-MAS [57]. Interestingly, a BODIPY-FF-MAS molecular probe was localized in nuclear lipid droplets of HepG2 cells. Such localization of FF-MAS is in line with the proposed regulatory role [57].

Functional genomics targeting components of the C4DMC led to highlights in human cholesterol biology. In a cancer cell line, the increased sensitivity to antagonists of an oncogenic epidermal growth factor receptor was revealed upon siRNA-based inactivation of SC4MOL and NSDHL leading to 4,4-dimethylzymosterol, 4-methylzymosterol, or 4-carboxysterol accumulation [90]. The inhibition of CYP51A1 suppressed the accumulation of these C4-SBIs and reversed the EGFR inhibitor sensibilization, rescuing cancer cell viability and EGFR degradation [90]. In human development, a hypomorphic temperature-sensitive allele of NSDHL causing the overaccumulation of 4-methylsterols in the cerebrospinal fluid was the cause of brain malformations typical of the CK syndrome (CKS) [49]. The SC4MOL-deficiency is an autosomal recessive lesion causing psoriasiform dermatitis, arthralgias, congenital cataracts, microcephaly, and developmental delay. Plasma sterol analysis showed a different cholesterol content in healthy individuals (140-176 $\left.\mathrm{mg} \cdot \mathrm{dL}^{-1}\right)$ versus patients (85-93 mg. $\left.\mathrm{dL}^{-1}\right)$. Most importantly, a ten-fold increase was obtained when measuring 4-methylsterols: $41-42 \mathrm{mg} \cdot \mathrm{mL}^{-1}$ in patients plasma compared to $2.8-3.2 \mathrm{mg} \cdot \mathrm{mL}^{-1}$ in healthy 
individuals [50]. In total, C4-SBIs presented a huge 500-fold increase in diseased individuals compared to healthy ones. No 4-carboxylmethylsterols neither 4-methylsterones were however detected. In such patients, fibroblasts had a 3-fold reduced rate of cell division, and immunocytes were abnormal, this was mimicked by applying aminotriazole, an inhibitor of SC4MOL/SMO. A causal relationship between the accumulation of C4-SBIs and skin barrier function, cell proliferation and immune regulation was then established [50]. Furthermore, the same authors demonstrated that C4-SBIs negatively regulate the epidermal growth factor receptor (EGFR), signaling and vesicular trafficking [91].

The Congenital Hemidysplasia with Ichthyosiform nevus and Limb Defects (CHILD) syndrome is a rare $X$-linked dominant disease with lethality for male embryos, sensorineural hearing loss, normal intelligence in females and one-sided cerebral hypoplasia [48]. More than 20 different alleles of the NSDHL gene were described $[48,92,93]$.

Sterol analysis were performed in $n s d h l$ mice: skin fibroblasts of bare patches of such mice contained about $20 \%$ of C4-SBIs in total sterols (71.4\% of cholesterol, $18.2 \%$ of 4 -methylsterols and 1.1 of 4,4-methylsterols), while control male mice had less than $0.1 \%$ of C4-SBIs and $99.9 \%$ of cholesterol [70]. The CKS consists of mild to severe intellectual disability in males, microcephaly, CNS malformation, seizures, hypotonia, dysphasia/speech delay, behavioral problems and possible psychopathological issues in female carriers. The CKS is lethal in females (whereas CHILD is lethal to males). Cerebrospinal fluid from CKS patients is enriched in 4-methylsterols and is low in cholesterol. It is also reported that CKS patients display a deficient hedgehog signaling [49]. No mutation (and associated human genetic disease) was reported in the case of C4D and ERG28. In mouse, the Rudolph mutant carries an allele of the C4D/HSD17B17 gene causing defective growth and patterning of the CNS, skeleton malformation, and an altered hedgehog signaling associated to an accumulation of zymosterone and 4-methylzymosterone [94]. The study of a conditional nsdhl mouse allele enabled a refined understanding of the link between cholesterol homeostasis and CNS at various developmental stages of pups. NSDHL deficiency and its associated accumulation of 4-methylsterols was responsible for defects in the cerebellum, hippocampus, cerebral cortex and led to early postnatal lethal phenotype [95]. At the cellular level, these defects were a thinner layer of granule cell precursors, which play a critical role in cerebral, cortical and hippocampal neuronal proliferation, differentiation and migration before birth. Using this $n s d h l$ mouse line, an in vitro cell system was established from granule cell precursors to test the effect of 4-methylsterols on sonic hedgehog signaling (SHH). The obtained cell lines were cultivated with LDL supplementation and also ketoconazole treatment, in order to restore a cholesterol content, and to block the accumulation of 4-methylsterols, respectively. A hampered SHH signaling was correlated with the accumulation of 4-methylsterols. T-MAS (a functional 4-methylsterol), when added to wild-type cells obtained from granule precursors, mimicked perfectly the biogenetic accumulation otherwise noticed in conditional nsdhl cells, however no effect on SHH signaling was observed, most probably due to a mislocalization of T-MAS, or to the lack of bioconversion of T-MAS into an active yet unknown sterol-derived inhibitor of the $\mathrm{SHH}$ pathway.

C4-SBIs were described as essential players in the immune system. The binding capacity of C4-SBIs to the nuclear hormone receptor ROR $\gamma \mathrm{t}$, an active component of lymphoid cells in thymus, was tested in vitro and in vivo [25]. 4-methylsterol biosynthetic intermediates in between the lanosterol to $4 \alpha$-methylcholesta-8,24-dien-3-one (the substrate of C4D/HSD17B7) segment (Figure 2) exhibited the properties of ligands of ROR $\gamma \mathrm{t}$ albeit with significant affinity variations. 4-Methylsterols displayed the weaker affinity while oxygenated C4-SBIs like $4 \alpha$-carboxy- $4 \beta$-methylzymosterol (Figure 1) had a higher affinity. This study highlighted the regulatory role of bona-fide cholesterol biosynthetic intermediates upon immune system development and lymphoid functions. C4-SBIs have also a positive influence on mice oligodendrocyte formation and remyelination, as shown using sterol biosynthesis inhibitors. Inhibitors of C4-demethylation and of C14-reduction and $\Delta^{8}-\Delta^{7}$ isomerization (that promote the accumulation of C4-SBIs indirectly) led to the inactivation of a transcriptional 
program via the SREBP nuclear hormone receptors $[40,96]$. Further studies are required to identify firmly which C4-SBIs activate the SREBP machinery.

Table 1. IUPAC sterol nomenclature [97].

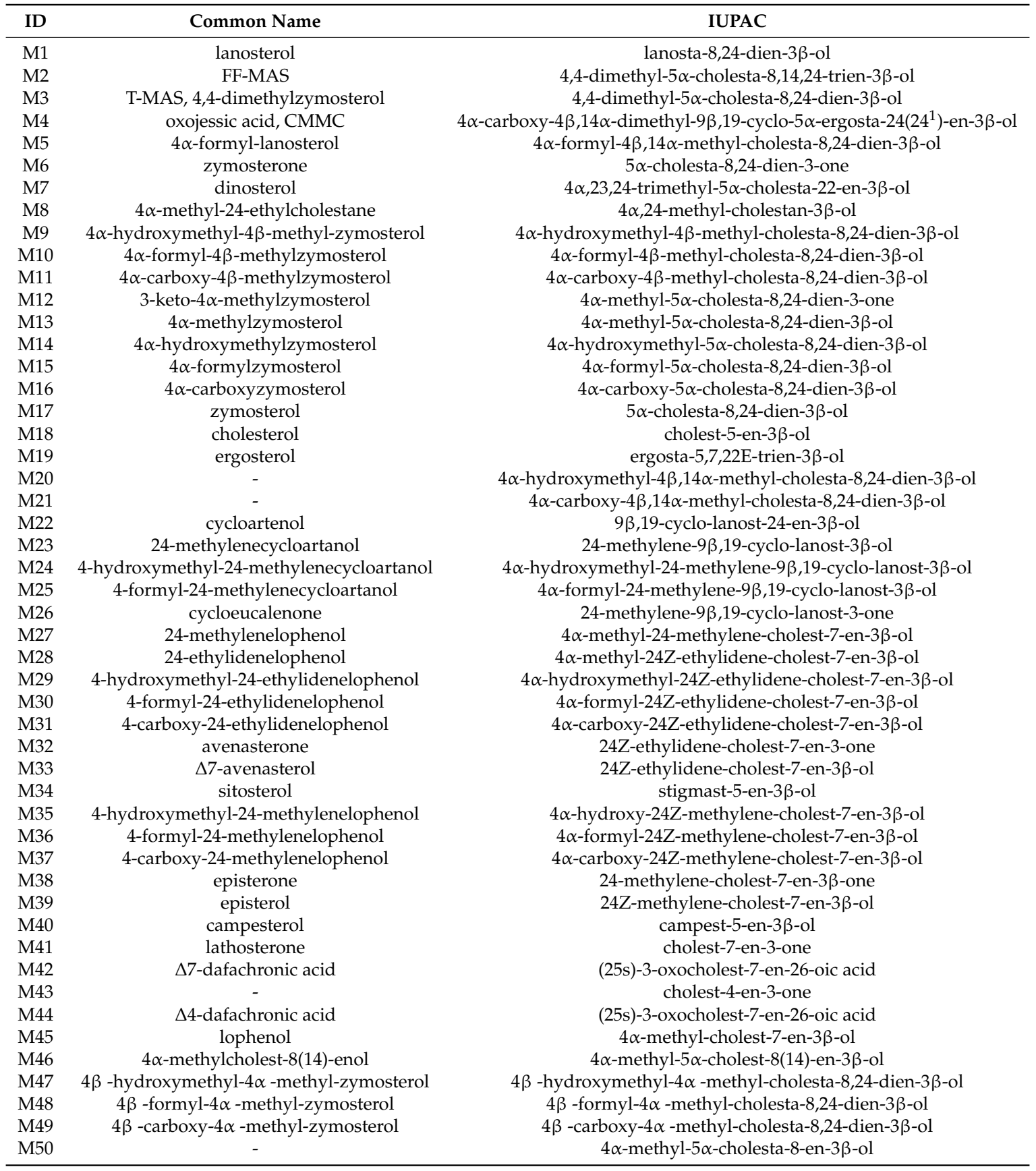

\section{Saccharomyces cerevisiae, a Versatile Model for Sterol Genetics and Auxotrophy Studies}

The yeast $S$. cerevisiae has established itself as a privileged model for the identification of sterol biosynthesis genes [98,99]. The advantages of yeast are plentiful: a sterol biosynthesis pathway similar to that of animals or plants enabling metabolic interferences, the possibility of homologous recombination to create loss-of-function mutants, its ability to have an uptake of exogenous sterols, to mention a few. The identification of the yeast SMO gene was published independently in 1996 by two teams. The Kaplan team screened a yeast mutant deficient in SMO activity based on its limited 
heme biosynthetic capacities [100]. The Bard team isolated the erg25/smo mutant by screening for SMO activity deficiency and identified the ERG25 gene (Figure 2) [101]. The yeast C4D was identified based on its functional homology with an NAD(P)-dependent cholesterol dehydrogenase gene of Nocardia sp. [102]; it complemented a corresponding deficient yeast (erg26) and Candida albicans mutants [103,104]. The yeast SKR gene encoding ERG27/SKR complemented a null mutant erg27 deficient in 3-ketosteroid reductase (Figure 2) [105]. Gene expression analysis pointed out ERG28 and ergosterol biosynthetic genes within the same levels of expression [106]. The disruption of ERG28 induced a loss of C4-demethylation activity [107]. Protein interaction studies showed that ERG25, ERG26, ERG27, and ERG28 proteins are assembled in a complex tethered by ERG28 [108]. Although ergosterol biosynthesis was tremendously studied, some components of the machinery like ERG29 (an ER-associated protein) were unveiled just very recently [109].

The yeast $\operatorname{erg} 25$ mutant contains high amounts of 4,4-dimethylsterols that are more effective than 4,4,14-trimethylsterols (like lanosterol) to disrupt growth. The lethality of erg 25 was overcome by mutations in ERG11 (lanosterol-14-demethylase) and SLU (suppressor of lanosterol utilization) to prevent the accumulation of 4,4-dimethylsterols and consequently ergosterol auxotrophy [110]. In the fission yeast Schizosaccharomyces pombe, the overexpression of ERG25 affected proper cytokinesis: the accumulation of 4,4-dimethylzymosterol-downstream products and further compositional changes in sterol/lipid-rich membrane domains led to defects in actomyosin ring positioning and maintenance [111]. The isolation of a yeast thermosensitive mutant erg $26-1$ defective in the decarboxylation of 4-carboxy-4-methylsterols revealed the inefficiency of these C4-SBIs to support growth as bulk components. Protein-protein interaction studies pointed out a function for ERG26 in ERG7 regulation [112] and also in lipid homeostasis [107,112,113]. ERG29 was identified as an interactant or modulator of SMO/ERG25. The loss of ERG29 resulted in the accumulation of C4-SBIs and affected cell viability. In these yeast cells, an increase of mitochondrial oxidants and the degradation of the mammalian frataxin ortholog involved in mitochondrial iron-sulfur (Fe-S) cluster synthesis showed a link between sterol composition and iron metabolism in the mitochondrial compartment [109]. The expression of a gene cluster for helvolic acid production into Aspergillus oryzae NSAR1 has revealed the identification of C4-SBIs bearing anti-Staphylococcus aureus properties and unsual C4-demethylation enzymes [114]. In S. pombe, C4-SBIs have been identified as signaling molecules acting as oxygen sensor by interacting with the SRE1/SCP1 complex, which is equivalent to the mammalian SREBP regulatory pathway responsible for cholesterol homeostasis. Under conditions of low oxygen and cell stress, C4-SBIs accumulate and activate the transcription factor SRE1 [115].

\section{The Plant-Specific Sterol-C4-Demethylation Process and Its Influence upon Development}

Sterol-4 $\alpha$-methyl oxidase (SMO) is the enzyme of the C4DMC that acts first in the sequence of reactions. SMO enzymatic activities were initially studied with microsomal fractions of Zea mays coleoptiles incubated with radioactively labeled sterol substrates. This led to the clear-cut identification and characterization of two distinct SMO activities. These two SMO activities were shown to occur in a non-consecutive manner in the sterol pathway: a first SMO oxidizes 4,4,14-trimethylcyclopropylsterols such as 24-methylenecycloartanol, and a second SMO oxidizes $4 \alpha$-methyl- $\Delta^{7}$-sterols such as 24-ethylidene lophenol (Figure 2 and Figure S1) [21]. It was also demonstrated that electrons are supplied via NADH to the oxygenase by the cytochrome b5/cytochrome b5 reductase system [116]. These distinct subcellular SMO activities corresponded in planta to the expression of distinct plant orthologs of the yeast SMO belonging to the SMO1 and SMO2 gene families [117]. When expressed in a yeast erg 25 mutant, SMO1 and SMO2 conferred different sterol biosynthetic capacity to their host $[117,118]$. Recently, the characterization of a cholesterol-specific biosynthetic segment in the Solanaceae (containing solanine or tomatine, which are steroidal glycoalkaloid derived from cholesterol) unveiled the function of additional SMO1 and SMO2 orthologs (named SMO3 and SMO4) that act specifically on C4-SBIs bearing cholesterol-type side chains [119]. Consequently, each SMO1 
or SMO2 define distinct C4DMC comprising C4D, SKR, and ERG28. Two C4D (3ß-hydroxysteroid dehydrogenase/C4-decarboxylase) were found to act redundantly in both types of C4DMC [120]. The plant SKR and ERG28 genes were functionally identified in protein-protein interaction assays and planta with the implementation of RNA silencing (RNAi) or knock-out T-DNA insertion lines [52]. Interestingly, the Arabidopsis SMO1-1 and SMO1-2 isoforms were identified as interactants of an Acyl-CoA-Binding Protein 1 (ACBP1) in yeast double hybrid assays, strongly suggesting a role for a SMO/ACBP1 complex in the regulation of lipid metabolism and particularly the activity of acyltransferases governing the production of triacylglycerols and sterol esters [121,122]. Also, it is proposed that the SMO1/ACBP1 complex controls plant development via an unknown lipid ligand that activates transcription factors like GLABRA2, HDG5, HDG10 [121,122]. The regulatory action of SMO1, possibly as a limiting step in phytosterol biosynthesis or by an unknown signaling activity of C4-SBIs, was illustrated in A. thaliana expressing jointly 3-hydroxy-3-methylglutaryl-coenzyme A reductase (HMGR) and SMO1 increasing by $54 \%$ in biomass [123].

The physiological functions of C4-SBIs were investigated using the elegant virus-induced gene silencing strategy (VIGS) in Nicotiana benthamiana, as already established in the case of the C14-demethylation step (CYP51; [124]). VIGS of SMO1 and SMO2 indicated deficiencies in distinct entities based on distinct sterol profiles: SMO1-silenced plants exhibited 4,4-dimethyl-9 $\beta, 19$-cyclopropylsterols as major sterols whereas SMO2-silenced plants had $4 \alpha$-methyl- $\Delta^{7}$-sterols [117]. The same approach was successfully implemented to characterize a C4D gene in N. benthamiana: the dramatic reduction in gene expression resulted in the accumulation of the 4-carboxymethyl-4-methylsterol substrate of C4D in silenced leaves [120]. In SMO2 silenced plants, changes in the activity of the C4DMC caused a subsequent increase (compared to wild-type) of the ratio of C24-methylsterols to C24-ethylsterols in the sterol profiles. 24-Methylenelophenol is the substrate of SMO2 and also of the sterol-C24-methyltransferase SMT2 [125-127], and consequently defines a branching point in plant sterol biosynthesis (Figure 2). Therefore, the down-regulation or overexpression of SMO2 indirectly modulate the ratio of 24-methylsterols to 24-ethylsterols (mainly, campesterol to sitosterol), causing deleterious effects on growth [24]. Biotic interactions at the sterol metabolism interface were also studied in the context of silenced SMO genes in N. benthamiana to investigate the replication of tombusviruses (TBSV, tomato bushy stunt virus), a group of viruses depending on cellular membranes for replication. The authors also implemented a chemical treatment of plants with 6-amino-2-n-pentylthiobenzothiazole (APB), an inhibitor of the fungal SMO [128]. Silencing of SMOs and APB treatment reduced virus replication. Notably, APB was effective in slowing down virus replication in N. benthamiana protoplasts. Exogenous addition of campesterol and sitosterol in the medium rescued replication of the virus. The authors have also tested the effect of sterol biosynthesis inhibition by APB on tobacco mosaic virus (TMV) replication and showed that TMV accumulation was sterol-independent. The authors proposed two explanations accounting for the difference in replication between the TBSV and TMV in their host plant: i) tombusviruses proteins are integrated into membranes and interact with sterols; ii) each type of virus replicate in distinct subcellular compartments having specific sterol composition [128].

Functional aspects of C4-SBIs were investigated in A. thaliana by overexpressing or knocking-out genes of interest and scrutinizing their associated phenotype. A. thaliana overexpressing C4D displayed a short internode phenotype that was not rescued by brassinosteroids. The authors suggested that the accumulation of 3-ketosterols, the products of C4D like 22-hydroxy-5 $\beta$-ergostan-3-one would alter membrane properties, auxin transporter activity and consequently growth and development (Figure 2) [129]. This conclusion is also in line with possible modification of the sterol composition of membrane microdomains, which are tremendously important in cellular homeostasis and signaling [130]. The characterization of loss-of-function smo2 alleles in A. thaliana required double null mutants of both SMO2-1 and SMO2-2, to deal with genetic redundancy [117]. The complete loss of SMO2 was lethal or at least resulted in an early arrest in embryogenesis [131]. However, 
heterozygote (smo2-1/smo2-1, smo2-2/+) were dwarfs and late-flowering plants, with phenotypic features like small round dark green leaves reminiscent of some other sterol biosynthetic mutants bearing genetic defects in the conversion of $\Delta^{7}$-sterol intermediates to $\Delta^{5}$-sterols (campesterol and sitosterol) [132-136]. The sterol profiles of heterozygote smo2-1/smo2-2 lines showed a marked accumulation of C4-SBIs such as 24-ethylidenelophenol up to $20 \%$ of the total and a decrease in campesterol and stigmasterol [131]. A careful examination of the phenotypic traits of smo2 plants pointed out very clearly their impaired response to auxin [131]. The exogenous application of auxin or the introgression of $s m o 2$ mutations in auxin overproducer lines such as those overproducing free IAA upon enhancement of the YUCCA gene expression resulted in the rescue a wild-type developmental phenotype in smo2 loss-of-function mutants [131]. It is conceivable that the accumulation of C4-SBIs alters plasma membrane properties, particularly the proper localization of auxin efflux PIN proteins, as shown earlier $[137,138]$. Alternatively, C4-SBIs may act as components of auxin signaling. This was proposed by independent studies consisting in altering the expression of an enzyme of C4DMC (C4D; [129]) or of ERG28, the non-enzymatic protein that tethers the C4DMC [52]. In the latter study, several $\operatorname{erg} 28$ knocked-down Arabidopsis lines displayed an abnormal accumulation of the transient C4-SBI oxojessic acid (in $\mu \mathrm{g} \cdot \mathrm{g}^{-1}$ fresh weight amount compared to undetectable signals in wild-type plants). Phenotypes of such plants were reminiscent of an auxin disrupted homeostasis: in fact, experimental evidence supports the function of oxojessic acid as an inhibitor of polar auxin transport [52]. Taken together these results point out a novel critical role for C4-SBIs on growth and development that is distinct from the status of sterol end-products or brassinosteroids.

\section{Caenorhabditis elegans: A Sterol Auxotroph with an Extraordinary C4-Methylation Capacity}

Nematodes are sterol auxotrophs, just like insects and some other invertebrates. These organisms live on exogenous sterols provided by their diet. They also convert a proportion of cholesterol into steroid hormones known as the dafachronic acids, which bind the nuclear hormone receptor DAF12 responsible for reproductive development (Figure 3) [139]. In fact, the biogenesis of these compounds requires $\mathrm{C} 4$-desmethylsterols as substrates (i.e., cholesterol, with a free $\mathrm{C} 4$ position) and the action of a 3-hydroxysteroid dehydrogenase $/ \Delta^{5} / \Delta^{4}$ isomerase (HSD-1) for the conversion of cholesterol to cholest-4-en-3-one en route to dafachronic acid (Figure 3) [51,139]. The arrest of the reproductive cycle upon environmental stress requires the inactivation of dafachronic acid biogenesis that enables unbound DAF12-mediated larval entry into the dauer stage, a particular diapause. Quite uncommon in the eukaryotic tree of life, a sterol-C4-methyltransferase named STRM-1 catalyzes the addition of a single methyl group provided by $S$-adenosyl-methionine onto the sterol tetracyclic moiety. The products of the methylation reaction like lophenol or its isomeric $4 \alpha$-methyl- $5 \alpha$-cholest-8(14)-en-3 $\beta$-ol are sterol biosynthesis end-products rather than C4-SBIs in this particular context (Figure 3) [51]. The enzymatic reaction catalyzed by STRM-1 has not been investigated into much detail. This sterol methylation restricted to nematodes regulate the biologically active amounts of dafachronic acids, pointing out the tremendous importance of 4-methylsterols in development since it is the C4-methylated product that triggers the entry of the worm into the dauer stage $[139,140]$. 


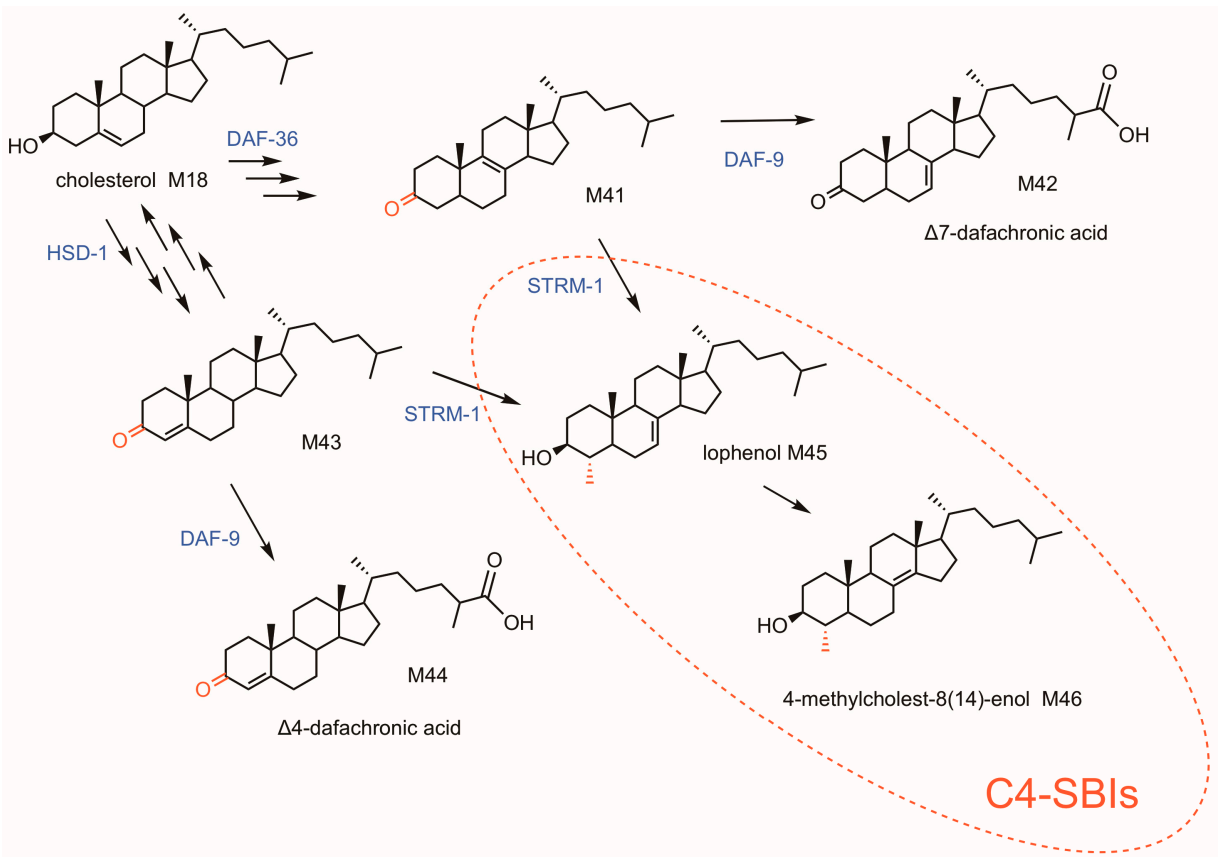

Figure 3. Dafachronic acid synthesis in Caenorhabditis elegans. Sterol nomenclature is given in Table 1. C4-demethylation in eukaryotes: HSD-1, 3-hydroxysteroid dehydrogenase $/ \Delta 5 / \Delta 4$ isomerase (HSD-1); STRM-1, Sterol 4-C-methyltransferase; DAF-9, steroid cytochrome P450 hydroxylase; DAF-36, cholesterol 7-desaturase. Each arrow represents an enzymatic step.

\section{Bacteria Evolved Their Specific C4-Demethylation Enzymes}

The capacity to synthesize sterols is usually not a prokaryotic feature. However, genes encoding the steroidal triterpene forming enzyme 2,3-oxidosqualene cyclase (OSC) were found in 34 bacterial genomes from several phyla (myxobacteria, methylococcales, rhizobiales, planctomycetes, and some others), thus predicting putative or minimal sterol pathway comprising 2,3-oxidosqualene cyclization products and subsequent C14 and C4 demethylations of those (Figure 4) [141]. Interestingly, $\gamma$-proteobacterial aerobic methanotrophs like Methylococcus capsulatus are characterized by a $\mathrm{C} 4$ demethylation process removing one single methyl group at C4-position of 4,4-dimethylsterols, whereas $\delta$-proteobacterial myxobacteria can remove both methyl groups at $\mathrm{C} 4$ like it is the case in eukaryotes [141]. The single C4 demethylation that is typical of M. capsulatus is catalyzed by the consecutive action of two enzymes (Figure 4 and Figure S1C). These sterol demethylation (Sdm) enzymes are strikingly different from the eukaryotic C4-demethylation enzymes described above. $\mathrm{SdmA}$ is a Rieske-type oxygenase that catalyzes three successive oxidations of the C $4 \beta$ methyl group of 4,4-dimethylsterols, whereas the non-heme oxygenase SMO performs the successive oxidation reactions of the $\mathrm{C} 4 \alpha$ methyl group of 4,4-dimethylsterols in eukaryotes. Rieske-type oxygenases have been described in sterol pathways of dafachronic acids in C. elegans [142] and of the protist Tetrahymena thermophila $[143,144]$ where that type of enzymes acts as a cholesterol-7-desaturase. SdmB is the second enzyme responsible for both decarboxylation and ketoreduction steps. The reversibility of the last step has been discussed [141]. These findings demonstrate that a sterol-C4-demethylation process has evolved twice independently and that the bacterial Sdm enzymes are functionally restricted to demethylate at $C 4 \beta$ without any further oxidation at $C 4 \alpha$, explaining thus the production of $C 4$-SBIs as pathway end-products in methanotrophs otherwise used as geological biomarkers. The function of 4-methylsterols in bacteria is not clearly understood. A role in adaptation to environmental constraints like water salinity or limitation in oxygen has been suggested [141]. 


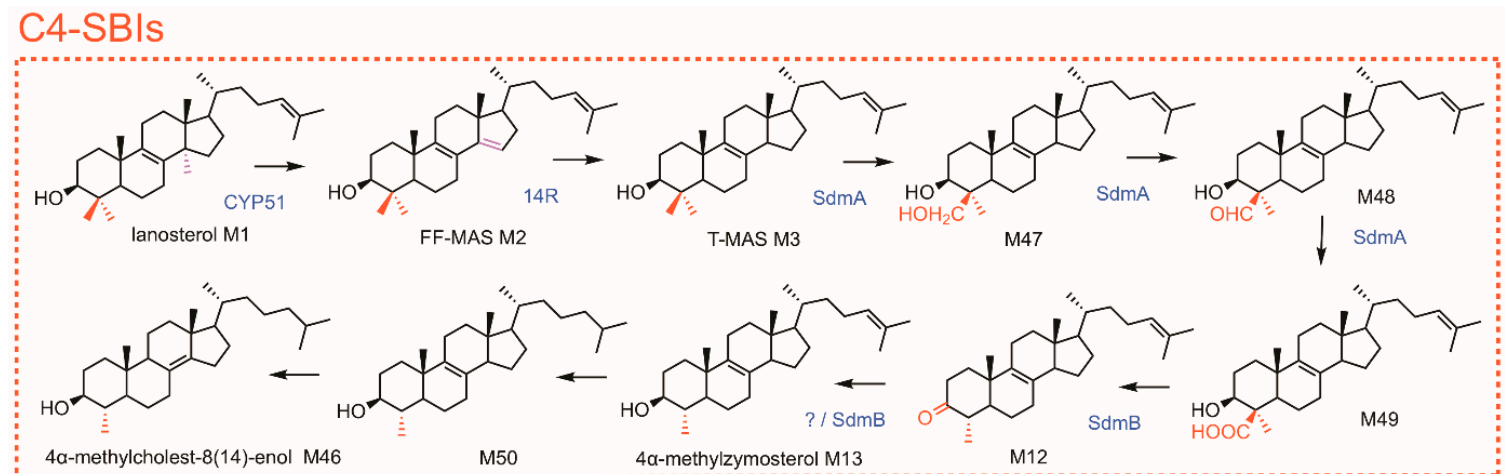

Figure 4. Sterol pathways in Methylococcus capsulatus. Sterol nomenclature is given in Table 1. CYP51, lanosterol-C14 demethylase; 14R, sterol-14-reductase; Sdm, sterol demethylase. Each arrow represents an enzymatic step.

\section{Inhibitors of C4-SBIs Accumulation In Vivo, Canonical and Non-Canonical C4-SBIs, and Conjugated forms}

The overall chemical or genetic inhibition studies of C4-demethylation steps of cholesterol (plants and mammals), ergosterol (fungi, algae) or phytosterol biosynthesis demonstrate that the removal of both methyl groups at C4-position are necessary for proper growth or development. The accumulation of lanosterol results from the inhibition of the sterol-C14-demethylase, that is a P450-dependent mono-oxygenase. The class of 'azoles', that includes imidazoles and triazoles, is widely used as therapeutic and agricultural antifungal drugs [145,146]. For instance, clotrimazole is used to monitor C4-SBI accumulation in yeast and human (Figure 5) [40,147]. It is worth noting that the accumulation of C4-SBIs may be caused by inhibitors acting in fact on the sterol-C14-reduction and sterol-C8-isomerization steps like the morpholine derivative amorolfine or the compound AY9944 [40,57,148].

It is therefore relevant to envision the SMO, C4D, and SKR enzymes as interesting target sites for new fungicides or herbicides. In yeast, APB (Figure 5) inhibited sterol-C4-demethylation [149]. APB was assayed in vitro on maize coleoptile microsomal SMO1 and SMO2 enzymatic activities: surprisingly, APB did not affect SMO1 whereas it displayed a limited inhibition of SMO2 (compared to the strong effect observed on the yeast SMO) [150-152]. Other compounds like PF1163A and PF1163B were isolated from Penicillium sp. PF1163A (Figure 5) caused a steady accumulation of 4,4-dimethylzymosterol in yeast indicating SMO as the target of these new antifungal antibiotics [153-155]. Garlic extract and 17-hydroxyprogesterone inhibited human SMO [57,156,157], 3-amino-1,2,3-triazole (ATZ) was described as a potent SMO inhibitor in mice [91,158,159], the cholesterol-lowering oxysteroid FR171456 (Figure 5) was recently characterized for its inhibitory property on C4-decarboxylation enzymes (NSDHL in human, ERG26 in yeast) [160]. Fenhexamid (a hydroxyanilide) and fenpyrazamine (an aminopyrazolinone) are antifungal agents presently on the market. The fungal sterol profiles established in the presence of fenhexamid displayed an accumulation of 3-ketosterols (zymosterone), showing that the inhibition of SKR was most probably the reason of fungitoxicity [161]. 

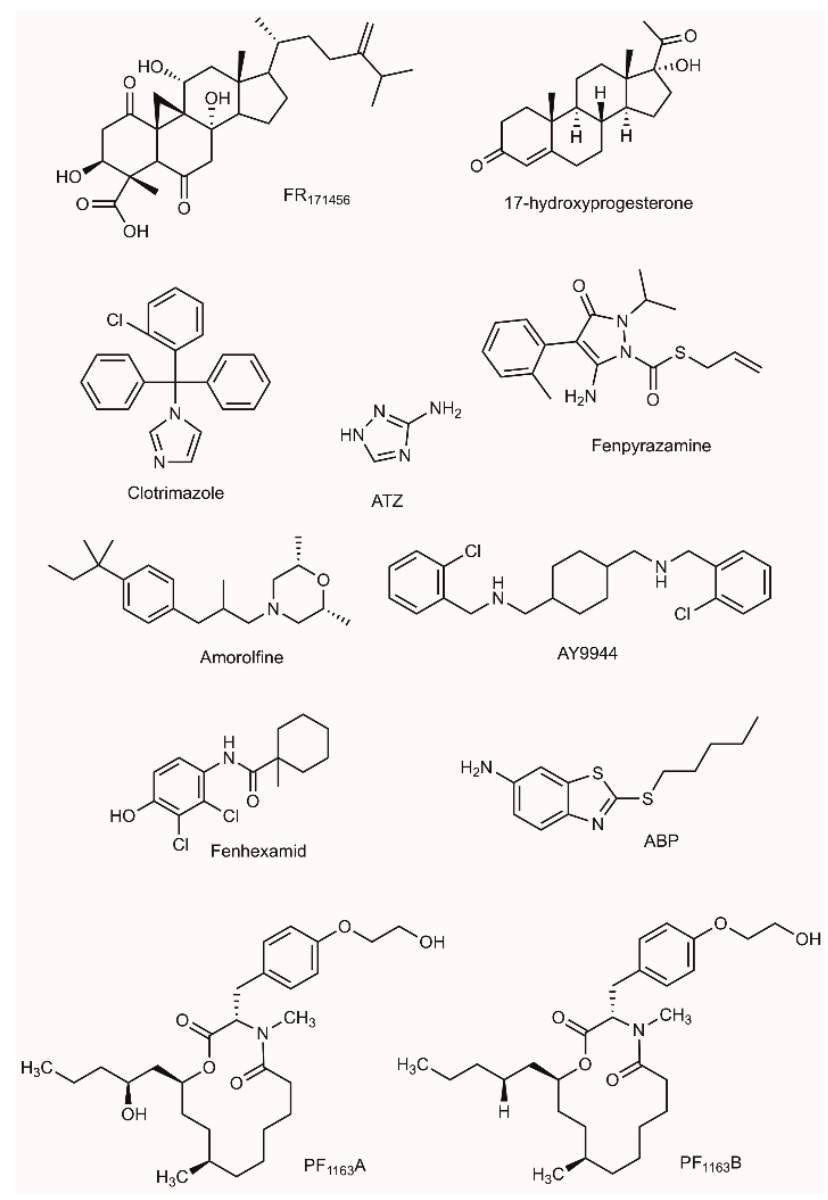

Figure 5. Chemical inhibitors for C4-SBI accumulation.

The classification of canonical and non-canonical C4-SBIs was proposed by the WD Nes (Texas Tech University, Lubbock, TX, USA) and the Littman (Howard Hugues Medical Institute, Chevy Chase, MD, USA) groups [25]. This definition is based on a thorough chemical analysis of oxysterols binding the nuclear receptor $\operatorname{ROR} \gamma$, this in several genetic backgrounds of mice carrying loss-of-function mutations of the enzymes CYP51 (sterol-C14-demethylation) or in SC4MOL/SMO (sterol-C4-demethylation). Canonical oxygenated metabolites derived from the major C4-SBIs T-MAS and $4 \alpha$-methylzymosterol (Figure 2A) are generated by three successive SMO-catalyzed oxidations of the methyl group at $\mathrm{C} 4$ yielding a 4-hydroxymethylsterol, a 4-formylsterol and a 4-carboxysterol transient sterol biosynthesis intermediates (Figure 2A). These C4-SBIs are usually not detected in routine sterol profiling of given organs or tissues and for this reason, could be even considered as cryptic. However, an inhibitor of SMO fed to a yeast microsomal fraction enabled the identification of 4-hydroxymethylsterols, namely, $4 \beta$-methyl- $4 \alpha$-hydroxymethyl- $5 \alpha$-cholesta-8,24-dien-3 $\beta$-ol and $4 \alpha$-hydroxymethyl- $5 \alpha$-cholesta-8,24-dien-3 $\beta$-ol [152]. Likewise, carboxysterols and ketosterols were identified in yeast, plants, and mammals following chemical or genetic inhibition. In the case of plants, C4D gene silencing in $N$. benthamiana led to a remarkable accumulation of $3 \beta$-hydroxy-4 $\beta$,14-dimethyl- $5 \alpha$-ergosta-9 $\beta, 19$-cyclo-24(28)-en- $4 \alpha$-carboxylic acid [120].

In mammals, non-canonical oxygenated C4-SBIs are produced by the action of SMO on lanosterol before its demethylation at C14 (Figure 2A). Lanosterol was shown to be a substrate of the S. cerevisiae SMO [152]. Non-canonical oxygenated compounds are therefore 4-hydroxymethyl-14-methylsterols, 4-formyl-14-methylsterols, and 4-carboxymethyl14-methylsterols [25]. Mice thymus contained concentrations of about $60 \mathrm{nM} 4$-hydroxymethyl-4,14dimethylcholesta-8,24-dien-3 $\beta$-ol [25]. Non-Canonical C4-SBIs bearing a 14-hydroxymethyl or 14-carboxymethyl group were identified in previous studies on the C14-demethylation reaction. 
14-hydroxymethyl-4,4-dimethylcholesta-8,24-dien-3 $\beta$-ol accounted for about $1 \%$ of total cellular sterol in hepatocytes [162]. The range of non-canonical C4-SBIs is therefore due to the versatility of SMOs that can react as $4 \alpha$-methylsterol-oxidases on a variety of 4,4-dimethyl- and 4-methylsterol substrates [152].

Conjugated forms of C4-SBIs have been over-looked in biology. Many of these compounds belong to the so-called specialized metabolites (of plants, of protists, of bacteria). Lanosterol glycosides were reported in Muscari paradoxum [163]. Cycloartenol esters of fatty acids were found in Ixora coccinea [164]. In the marine diatom Skeletonema marinoi, sterol sulfates were associated with programmed cell death that occurs as a mechanism regulating phytoplankton blooms [165]. In mammals, the inhibition of SMO by an aminotriazole drug fed to rats resulted in a peroxisomal accumulation of $4 \alpha$-methylcholest-7-en-3 $\beta$-ol and its corresponding ester of fatty acids ( $18 \%$ of esters and $82 \%$ of free $3 \beta-\mathrm{OH}$ form). In the same tissues, 4,4-dimethylcholest- 8 -en- $3 \beta$-ol was found in its free form only, whereas the total cholesterol included $12 \%$ of cholesterol esters [158,159]. C4-SBIs were found as sulfates in patients suffering familial hypercholesterolemia and treated with partial ileal bypass surgery [166]. The function of these sulfates was not well perceived until recent studies in mice proposed for sterol sulfates the role of agonists of the endogenous retinoic acid receptor-related orphan receptor $\gamma(\mathrm{ROR} \gamma)$. This receptor plays a crucial role in the differentiation of lymphocytes and autoimmune diseases [167]. The limited current understanding of the physiological role of conjugated C4-SBIs (glycosides, lipid esters, sulfolipids) as signaling molecules will require further research initiatives.

\section{Concluding Remarks}

Genes and their products responsible for sterol-C4-demethylation in mammals, yeast, plants, and bacteria have been quite well described by several groups over the last years, as shortly reviewed above. There are striking differences between bacteria and other organisms (protists, metazoans) regarding C4-demethylation mechanisms recruited during evolution. Plants use distinct C4DMC defined by substrate specificity: SMO1-based demethylation complex of 4,4-dimethylsterols and SMO2-based demethylation complex of 4-methylsterols, whereas other organisms demethylate 4,4-dimethylsterols and 4-methylsterols consecutively with a single SMO-based complex (of three enzymes and a tethering protein ERG28). In eukaryotes, genetic or chemical inhibition of the sterol-C4-demethylation may lead to the accumulation of significant amounts of C4-SBIs or transient C4-SBIs, but also of their oxygenated derivatives classified as canonical and non-canonical. The review of biological activities of 4-methylsterols characterized so far in different kingdoms shows clear common features. In yeast, in plants or mammals, the accumulation of C4-SBIs (including oxygenated derivatives) has deleterious effects on growth and development. In yeast and mammals, the role of C4-SBIs in cell division was shown. In plants and mammals, 4-methylsterols and 4-carboxysterols act as signaling molecules interfering with major pathways like auxin in plants and immune system in mammals. The major challenge remains the identification of physical interactions of sterol ligands with their targets. Another critical issue is the analytical scale of those biosynthetic intermediates: just like some oxysterols or brassinosteroids, 4-carboxysterols may be present at very low concentration, e.g., at "hormone-dose" and are therefore not detected in sterol profiles. For example in A. thaliana, bulk sterols were quantified 100-200 $\mu \mathrm{g} \cdot \mathrm{g}^{-1}$ fresh weight, canonical C4-SBIs $0.1-0.5 \mu \mathrm{g} \cdot \mathrm{g}^{-1}$ fresh weight, but brassinolide $4 \times 10^{-5} \mu \mathrm{g} \cdot \mathrm{g}^{-1}$ fresh weight. Finally, the fate of C4-SBIs as metabolic products requires further investigations, regarding the enzymes implied in this process, and the type of formed products, like for instance hydroxysteroids or sulfates as shown in a study of ROR $\gamma t$ receptors [167].

Supplementary Materials: Available online, Figure S1: C14 and C4 demethylation enzymatic reactions in eukaryotes and C4 demethylation in Methylococcus capsulatus. A, C14-demethylation: C14DM, lanosterol-C14 demethylase, 14R, sterol-14-reductase. B, C4-demethylation in eukaryotes: SMO, sterol-4 $\alpha$-methyl-oxidase; C4D, 3 $\beta$-hydroxysteroid dehydrogenases/C-4 decarboxylase; SKR, sterone ketoreductase. C, bacterial C4-demethylation: sdm, sterol demethylase. 
Funding: SD and HS are grateful to Centre National de la Recherche Scientifique for supporting an LIA initiative (International Associated Laboratory $n^{\circ} 1170,2017-2020$ ) between UFPA, Belém, and IBMP, Strasbourg.

Conflicts of Interest: The authors declare no conflict of interest. The funders had no role in the design of the study; in the collection, analyses, or interpretation of data; in the writing of the manuscript, or in the decision to publish the results.

\section{References}

1. Itoh, T.; Tamura, T.; Matsumoto, T. Methylsterol compositions of 19 vegetable oils. J. Am. Oil Chem. Soc. 1973, 50, 300-303. [CrossRef]

2. Phillips, K.M.; Ruggio, D.M.; Toivo, J.I.; Swank, M.A.; Simpkins, A.H. Free and Esterified Sterol Composition of Edible Oils and Fats. J. Food Compost. Anal. 2002, 15, 123-142. [CrossRef]

3. Villette, C.; Berna, A.; Compagnon, V.; Schaller, H. Plant Sterol Diversity in Pollen from Angiosperms. Lipids 2015, 50, 749-760. [CrossRef] [PubMed]

4. Moreau, R.A.; Nystrom, L.; Whitaker, B.D.; Winkler-Moser, J.K.; Baer, D.J.; Gebauer, S.K.; Hicks, K.B. Phytosterols and their derivatives: Structural diversity, distribution, metabolism, analysis, and health-promoting uses. Prog. Lipid Res. 2018, 70, 35-61. [CrossRef] [PubMed]

5. Guo, D.A.; Venkatramesh, M.; Nes, W.D. Developmental regulation of sterol biosynthesis in Zea mays. Lipids 1995, 30, 203-219. [CrossRef] [PubMed]

6. Benveniste, P. Biosynthesis and accumulation of sterols. Annu. Rev. Plant Biol. 2004, 55, 429-457. [CrossRef]

7. Nes, W.D. Biosynthesis of cholesterol and other sterols. Chem. Rev. 2011, 111, 6423-6451. [CrossRef]

8. Schaller, H. Sterol and steroid biosynthesis and metabolism in plants and microorganisms. In Comprehensive Natural Products II: Chemistry and Biology; Mander, L.N., Hung-Wen, L., Eds.; Elsevier: Amsterdam, The Netherlands, 2010; Volume 1, pp. 755-787.

9. Abe, I.; Rohmer, M.; Prestwich, G.D. Enzymatic cyclization of squalene and oxidosqualene to sterols and triterpenes. Chem. Rev. 1993, 93, 2189-2206. [CrossRef]

10. Gaylor, J.L.; Moir, N.J.; Seifried, H.E.; Jefcoate, C.R. Assay and isolation of a cyanide-binding protein of rat liver microsomes. J. Biol. Chem. 1970, 245, 5511-5513.

11. Trzaskos, J.M.; Bowen, W.D.; Fisher, G.J.; Billheimer, J.T.; Gaylor, J.L. Microsomal enzymes of cholesterol biosynthesis from lanosterol: A progress report. Lipids 1982, 17, 250-256. [CrossRef]

12. Trzaskos, J.M.; Bowen, W.D.; Shafiee, A.; Fischer, R.T.; Gaylor, J.L. Cytochrome P450-dependent oxidation of lanosterol in cholesterol biosynthesis. Microsomal transport and C32-demethylation. J. Biol. Chem. 1984, 259, 13402-13412. [PubMed]

13. Aoyama, Y.; Okikawa, T.; Yoshida, Y. Evidence for the presence of cytochrome P-450 functional in lanosterol $14 \alpha$-demethylation in microsomes of aerobically grown respiring yeast. Biochim. Biophys. Acta 1981, 665, 596-601. [CrossRef]

14. Rahier, A.; Taton, M. The $14 \alpha$-demethylation of obtusifoliol by a cytochrome P-450 monooxygenase from higher plants microsomes. Biochem. Biophys. Res. Commun. 1986, 140, 1064-1072. [CrossRef]

15. Rahier, A.; Taton, M. Plant Sterol Biosynthesis Inhibitors-The 14-Demethylation Steps, Their Enzymology and Inhibition. Biochem. Soc. Trans. 1990, 18, 52-56. [CrossRef] [PubMed]

16. Kim, H.B.; Schaller, H.; Goh, C.H.; Kwon, M.; Choe, S.; An, C.S.; Durst, F.; Feldmann, K.A.; Feyereisen, R. Arabidopsis cyp51 mutant shows postembryonic seedling lethality associated with lack of membrane integrity. Plant Physiol. 2005, 138, 2033-2047. [CrossRef]

17. Schrick, K.; Mayer, U.; Horrichs, A.; Kuhnt, C.; Bellini, C.; Dangl, J.; Schmidt, J.; Jurgens, G. FACKEL is a sterol C-14 reductase required for organized cell division and expansion in Arabidopsis embryogenesis. Genes Dev. 2000, 14, 1471-1484.

18. Lorenz, R.T.; Parks, L.W. Cloning, sequencing, and disruption of the gene encoding sterol C-14 reductase in Saccharomyces cerevisiae. DNA Cell Biol. 1992, 11, 685-692. [CrossRef]

19. Roberti, R.; Bennati, A.M.; Galli, G.; Caruso, D.; Maras, B.; Aisa, C.; Beccari, T.; Della Fazia, M.A.; Servillo, G. Cloning and expression of sterol $\Delta 14$-reductase from bovine liver. Eur. J. Biochem. 2002, 269, 283-290. [CrossRef] 
20. Waterham, H.R.; Koster, J.; Romeijn, G.J.; Hennekam, R.C.; Vreken, P.; Andersson, H.C.; FitzPatrick, D.R.; Kelley, R.I.; Wanders, R.J. Mutations in the $3 \beta$-hydroxysterol $\Delta 24$-reductase gene cause desmosterolosis, an autosomal recessive disorder of cholesterol biosynthesis. Am. J. Hum. Genet. 2001, 69, 685-694. [CrossRef]

21. Pascal, S.; Taton, M.; Rahier, A. Plant sterol biosynthesis. Identification and characterization of two distinct microsomal oxidative enzymatic systems involved in sterol C4-demethylation. J. Biol. Chem. 1993, 268, 11639-11654.

22. Bouvier, F.; Rahier, A.; Camara, B. Biogenesis, molecular regulation and function of plant isoprenoids. Prog. Lipid Res. 2005, 44, 357-429. [CrossRef] [PubMed]

23. Mo, C.; Bard, M. Erg28p is a key protein in the yeast sterol biosynthetic enzyme complex. J. Lipid Res. 2005, 46, 1991-1998. [CrossRef] [PubMed]

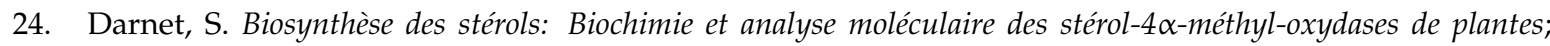
Université de Strasbourg: Strasbourg, France, 2004.

25. Santori, F.R.; Huang, P.; van de Pavert, S.A.; Douglass, E.F., Jr.; Leaver, D.J.; Haubrich, B.A.; Keber, R.; Lorbek, G.; Konijn, T.; Rosales, B.N.; et al. Identification of natural ROR $\gamma$ ligands that regulate the development of lymphoid cells. Cell Metab. 2015, 21, 286-298. [CrossRef] [PubMed]

26. Volkman, J.K.; Rijpstra, W.I.C.; de Leeuw, J.W.; Mansour, M.P.; Jackson, A.E.; Blackburn, S.I. Sterols of four dinoflagellates from the genus Prorocentrum. Phytochemistry 1999, 52, 659-668. [CrossRef]

27. Bouvier, P.; Rohmer, M.; Benveniste, P.; Ourisson, G. $\Delta 8(14)$-steroids in the bacterium Methylococcus capsulatus. Biochem. J. 1976, 159, 267-271. [CrossRef] [PubMed]

28. Volkman, J.K. Sterols and other triterpenoids: Source specificity and evolution of biosynthetic pathways. Org. Geochem. 2005, 36, 139-159. [CrossRef]

29. Fowler, M.G.; Douglas, A.G. Saturated hydrocarbon biomarkers in oils of Late Precambrian age from Eastern Siberia. Org. Geochem. 1987, 11, 201-213. [CrossRef]

30. Ourisson, G. Pecularities of Sterol Biosynthesis in Plants. J. Plant Physiol. 1994, 143, 434-439. [CrossRef]

31. Bloch, K.E. Sterol structure and membrane function. CRC Crit. Rev. Biochem. 1983, 14, 47-92. [CrossRef]

32. Gas-Pascual, E.; Berna, A.; Bach, T.J.; Schaller, H. Plant oxidosqualene metabolism: Cycloartenol synthase-dependent sterol biosynthesis in Nicotiana benthamiana. PLoS ONE 2014, 9, e109156. [CrossRef]

33. Barton, D.H.R. Triterpenoids. Part III. cycloartenone, a triterpenoid ketone. J. Chem. Soc. 1951, 1444. [CrossRef]

34. Goad, L.J. Aspects of Phytosterol Biosynthesis. In Terpenoids in Plants; Pridham, J.B., Ed.; Academic Press: London, UK, 1967; p. 159.

35. Lenton, J.R.; John Goad, L.; Goodwin, T.W. Sitosterol biosynthesis in Hordeum vulgare. Phytochemistry 1975, 14, 1523-1528. [CrossRef]

36. Dahl, C.E.; Dahl, J.S.; Bloch, K. Effect of alkyl-substituted precursors of cholesterol on artificial and natural membranes and on the viability of Mycoplasma capricolum. Biochemistry 1980, 19, 1462-1467. [CrossRef] [PubMed]

37. Volkman, J.K. Sterols in microorganisms. Appl. Microbiol. Biotechnol. 2003, 60, 495-506. [CrossRef] [PubMed]

38. Kawashima, H.; Ohnishi, M.; Ogawa, S. Distribution of Unusual Cholesterol Precursors, 4-Methyl- and 4, 4-Dimethylsterols with $\Delta 8$ Unsaturation, in Gonads of Marine Archaeogastropods. J. Oleo Sci. 2013, 62, 465-470. [CrossRef] [PubMed]

39. Lim, L.; Jackson-Lewis, V.; Wong, L.C.; Shui, G.H.; Goh, A.X.; Kesavapany, S.; Jenner, A.M.; Fivaz, M.; Przedborski, S.; Wenk, M.R. Lanosterol induces mitochondrial uncoupling and protects dopaminergic neurons from cell death in a model for Parkinson's disease. Cell Death Differ. 2012, 19, 416-427. [CrossRef] [PubMed]

40. Hubler, Z.; Allimuthu, D.; Bederman, I.; Elitt, M.S.; Madhavan, M.; Allan, K.C.; Shick, H.E.; Garrison, E.; Karl, M.T.; Factor, D.C.; et al. Accumulation of 8,9-unsaturated sterols drives oligodendrocyte formation and remyelination. Nature 2018, 560, 372-376. [CrossRef] [PubMed]

41. Rozman, D.; Cotman, M.; Frangež, R. Lanosterol $14 \alpha$-demethylase and MAS sterols in mammalian gametogenesis. Mol. Cell. Endocrinol. 2002, 187, 179-187. [CrossRef]

42. Byskov, A.G.; Andersen, C.Y.; Leonardsen, L. Role of meiosis activating sterols, MAS, in induced oocyte maturation. Mol. Cell. Endocrinol. 2002, 187, 189-196. [CrossRef]

43. Byskov, A.G.; Andersen, C.Y.; Nordholm, L.; Thogersen, H.; Xia, G.; Wassmann, O.; Andersen, J.V.; Guddal, E.; Roed, T. Chemical structure of sterols that activate oocyte meiosis. Nature 1995, 374, 559-562. [CrossRef] 
44. Grondahl, C.; Hansen, T.H.; Marky-Nielsen, K.; Ottesen, J.L.; Hyttel, P. Human oocyte maturation in vitro is stimulated by meiosis-activating sterol. Hum. Reprod. 2000, 15 (Suppl. 5), 3-10. [CrossRef] [PubMed]

45. Mitsche, M.A.; McDonald, J.G.; Hobbs, H.H.; Cohen, J.C. Flux analysis of cholesterol biosynthesis in vivo reveals multiple tissue and cell-type specific pathways. Elife 2015, 4, e07999. [CrossRef] [PubMed]

46. Alonso, F.; Cirigliano, A.M.; Davola, M.E.; Cabrera, G.M.; Garcia Linares, G.E.; Labriola, C.; Barquero, A.A.; Ramirez, J.A. Multicomponent synthesis of 4,4-dimethyl sterol analogues and their effect on eukaryotic cells. Steroids 2014, 84, 1-6. [CrossRef] [PubMed]

47. Blume, T.; Guttzeit, M.; Kuhnke, J.; Zorn, L. Two syntheses of FF-MAS. Org. Lett. 2003, 5, 1837-1839. [CrossRef] [PubMed]

48. Konig, A.; Happle, R.; Bornholdt, D.; Engel, H.; Grzeschik, K.H. Mutations in the NSDHL gene, encoding a 3ß-hydroxysteroid dehydrogenase, cause CHILD syndrome. Am. J. Med. Genet. 2000, 90, 339-346. [CrossRef]

49. McLarren, K.W.; Severson, T.M.; du Souich, C.; Stockton, D.W.; Kratz, L.E.; Cunningham, D.; Hendson, G.; Morin, R.D.; Wu, D.; Paul, J.E.; et al. Hypomorphic temperature-sensitive alleles of NSDHL cause CK syndrome. Am. J. Hum. Genet. 2010, 87, 905-914. [CrossRef] [PubMed]

50. He, M.; Kratz, L.E.; Michel, J.J.; Vallejo, A.N.; Ferris, L.; Kelley, R.I.; Hoover, J.J.; Jukic, D.; Gibson, K.M.; Wolfe, L.A.; et al. Mutations in the human SC4MOL gene encoding a methyl sterol oxidase cause psoriasiform dermatitis, microcephaly, and developmental delay. J. Clin. Investig. 2011, 121, 976-984. [CrossRef]

51. Hannich, J.T.; Entchev, E.V.; Mende, F.; Boytchev, H.; Martin, R.; Zagoriy, V.; Theumer, G.; Riezman, I.; Riezman, H.; Knolker, H.J.; et al. Methylation of the sterol nucleus by STRM-1 regulates dauer larva formation in Caenorhabditis elegans. Dev. Cell 2009, 16, 833-843. [CrossRef]

52. Mialoundama, A.S.; Jadid, N.; Brunel, J.; Di Pascoli, T.; Heintz, D.; Erhardt, M.; Mutterer, J.; Bergdoll, M.; Ayoub, D.; Van Dorsselaer, A.; et al. Arabidopsis ERG28 tethers the sterol C4-demethylation complex to prevent accumulation of a biosynthetic intermediate that interferes with polar auxin transport. Plant Cell 2013, 25, 4879-4893. [CrossRef]

53. Fisher, R.T.; Trzaskos, J.M.; Magolda, R.L.; Ko, S.S.; Brosz, C.S.; Larsen, B. Lanosterol $14 \alpha-$ Methyl Demethylase. J. Biol. Chem. 1991, 10, 6124-6132.

54. Stromstedt, M.; Rozman, D.; Waterman, M.R. The ubiquitously expressed human CYP51 encodes lanosterol $14 \alpha$-demethylase, a cytochrome P450 whose expression is regulated by oxysterols. Arch. Biochem. Biophys. 1996, 329, 73-81. [CrossRef] [PubMed]

55. Bennati, A.M.; Castelli, M.; Della Fazia, M.A.; Beccari, T.; Caruso, D.; Servillo, G.; Roberti, R. Sterol dependent regulation of human TM7SF2 gene expression: Role of the encoded $3 \beta$-hydroxysterol $\Delta 14$-reductase in human cholesterol biosynthesis. Biochim. Biophys. Acta 2006, 1761, 677-685. [CrossRef] [PubMed]

56. Bennati, A.M.; Schiavoni, G.; Franken, S.; Piobbico, D.; Della Fazia, M.A.; Caruso, D.; De Fabiani, E.; Benedetti, L.; Cusella De Angelis, M.G.; Gieselmann, V.; et al. Disruption of the gene encoding $3 \beta$-hydroxysterol $\triangle 14$-reductase (Tm7sf2) in mice does not impair cholesterol biosynthesis. FEBS J. 2008, 275, 5034-5047. [CrossRef]

57. Gatticchi, L.; Cerra, B.; Scarpelli, P.; Macchioni, L.; Sebastiani, B.; Gioiello, A.; Roberti, R. Selected cholesterol biosynthesis inhibitors produce accumulation of the intermediate FF-MAS that targets nucleus and activates LXRalpha in HepG2 cells. Biochim. Biophys. Acta Mol. Cell. Biol. Lipids 2017, 1862, 842-852. [CrossRef] [PubMed]

58. Tsai, P.L.; Zhao, C.; Turner, E.; Schlieker, C. The Lamin B receptor is essential for cholesterol synthesis and perturbed by disease-causing mutations. Elife 2016, 5, e16011. [CrossRef] [PubMed]

59. Olson, J.A., Jr.; Lindberg, M.; Bloch, K. On the demethylation of lanosterol to cholesterol. J. Biol. Chem. 1957, 226, 941-956. [PubMed]

60. Lindberg, M.; Gautschi, F.; Bloch, K.E. Ketonic Intermediates in the demethylation of lanosterol. J. Biol. Chem. 1957, 238, 1661-1664.

61. Pudles, J.; Bloch, K. Conversion of 4-hydroxymethylene- $\Delta 7$-cholesten-3-one to cholesterol. J. Biol. Chem. 1960, 235, 3417-3420.

62. Swindell, A.C.; Gaylor, J.L. Investigation of the component reactions of oxidative sterol demethylation. Formation and metabolism of 3-ketosteroid intermediates. J. Biol. Chem. 1968, 243, 5546-5555.

63. Miller, W.L.; Gaylor, J.L. Investigation of the component reactions of oxidative sterol demethylation. Oxidation of a 4,4-dimethyl sterol to a 4 beta-methyl-4 alpha-carboxylic acid during cholesterol biosynthesis. J. Biol. Chem. 1970, 245, 5375-5381. 
64. Miller, W.L.; Brady, D.R.; Gaylor, J.L. Investigation of the component reactions of oxidative demethylation of sterols: Metabolism of 4alpha-hydroxymethyl steroids. J. Biol. Chem. 1971, 246, 5147-5153. [PubMed]

65. Rahimtula, A.D.; Gaylor, J.L. Investigation of the component reactions of oxidative sterol demethylation. Partial purification of a microsomal sterol $4 \alpha$-carboxylic acid decarboxylase. J. Biol. Chem. 1972, 247, 9-15. [PubMed]

66. Billheimer, J.T.; Alcorn, M.; Gaylor, J.L. Solubilization and partial purification of a microsomal 3-ketosteroid reductase of cholesterol biosynthesis. Arch. Biochem. Biophys. 1981, 211, 430-438. [CrossRef]

67. Nelson, J.A.; Kahn, S.; Spencer, T.A.; Sharpless, K.B.; Clayton, R.B. Some Aspects of Substrate-Specificity in Biological Demethylation at C4 of Steroids. Bioorg. Chem. 1975, 4, 363-376. [CrossRef]

68. Gaylor, J.L.; Miyake, Y.; Yamano, T. Stoichiometry of 4-methyl sterol oxidase of rat liver microsomes. J. Biol. Chem. 1975, 250, 7159-7167. [PubMed]

69. Marijanovic, Z.; Laubner, D.; Moller, G.; Gege, C.; Husen, B.; Adamski, J.; Breitling, R. Closing the gap: Identification of human 3-ketosteroid reductase, the last unknown enzyme of mammalian cholesterol biosynthesis. Mol. Endocrinol. 2003, 17, 1715-1725. [CrossRef] [PubMed]

70. Liu, X.Y.; Dangel, A.W.; Kelley, R.I.; Zhao, W.; Denny, P.; Botcherby, M.; Cattanach, B.; Peters, J.; Hunsicker, P.R.; Mallon, A.M.; et al. The gene mutated in bare patches and striated mice encodes a novel 3ß-hydroxysteroid dehydrogenase. Nat. Genet. 1999, 22, 182-187. [CrossRef] [PubMed]

71. Ottolenghi, C.; Daizadeh, I.; Ju, A.; Kossida, S.; Renault, G.; Jacquet, M.; Fellous, A.; Gilbert, W.; Veitia, R. The genomic structure of c14orf1 is conserved across eukarya. Mamm. Genome 2000, 11, 786-788. [CrossRef] [PubMed]

72. Quinlan, R.A. DRUG DISCOVERY. A new dawn for cataracts. Science 2015, 350, 636-637. [CrossRef] [PubMed]

73. Makley, L.N.; McMenimen, K.A.; DeVree, B.T.; Goldman, J.W.; McGlasson, B.N.; Rajagopal, P.; Dunyak, B.M.; McQuade, T.J.; Thompson, A.D.; Sunahara, R.; et al. Pharmacological chaperone for alpha-crystallin partially restores transparency in cataract models. Science 2015, 350, 674-677. [CrossRef] [PubMed]

74. Zhao, L.; Chen, X.J.; Zhu, J.; Xi, Y.B.; Yang, X.; Hu, L.D.; Ouyang, H.; Patel, S.H.; Jin, X.; Lin, D.; et al. Lanosterol reverses protein aggregation in cataracts. Nature 2015, 523, 607-611. [CrossRef] [PubMed]

75. Shanmugam, P.; Barigali, A.; Kadaskar, J.; Borgohain, S.; Mishra, D.C.; Ramanjulu, R.; Minija, C.K. Effect of lanosterol on human cataract nucleus. Indian J. Ophthalmol. 2015, 63, 888-890. [CrossRef] [PubMed]

76. Chen, X.J.; Hu, L.D.; Yao, K.; Yan, Y.B. Lanosterol and 25-hydroxycholesterol dissociate crystallin aggregates isolated from cataractous human lens via different mechanisms. Biochem. Biophys. Res. Commun. 2018, 506, 868-873. [CrossRef] [PubMed]

77. Shen, X.; Zhu, M.; Kang, L.; Tu, Y.; Li, L.; Zhang, R.; Qin, B.; Yang, M.; Guan, H. Lanosterol Synthase Pathway Alleviates Lens Opacity in Age-Related Cortical Cataract. J. Ophthalmol. 2018, 2018, 4125893. [CrossRef] [PubMed]

78. Araldi, E.; Fernandez-Fuertes, M.; Canfran-Duque, A.; Tang, W.; Cline, G.W.; Madrigal-Matute, J.; Pober, J.S.; Lasuncion, M.A.; Wu, D.; Fernandez-Hernando, C.; et al. Lanosterol Modulates TLR4-Mediated Innate Immune Responses in Macrophages. Cell Rep. 2017, 19, 2743-2755. [CrossRef] [PubMed]

79. Song, B.L.; Javitt, N.B.; DeBose-Boyd, R.A. Insig-mediated degradation of HMG CoA reductase stimulated by lanosterol, an intermediate in the synthesis of cholesterol. Cell Metab. 2005, 1, 179-189. [CrossRef]

80. Nguyen, A.D.; McDonald, J.G.; Bruick, R.K.; DeBose-Boyd, R.A. Hypoxia stimulates degradation of 3-hydroxy-3-methylglutaryl-coenzyme A reductase through accumulation of lanosterol and hypoxia-inducible factor-mediated induction of insigs. J. Biol. Chem. 2007, 282, 27436-27446. [CrossRef]

81. Schiavoni, G.; Bennati, A.M.; Castelli, M.; Della Fazia, M.A.; Beccari, T.; Servillo, G.; Roberti, R. Activation of TM7SF2 promoter by SREBP-2 depends on a new sterol regulatory element, a GC-box, and an inverted CCAAT-box. Biochim. Biophys. Acta 2010, 1801, 587-592. [CrossRef]

82. Subramanian, G.; Chaudhury, P.; Malu, K.; Fowler, S.; Manmode, R.; Gotur, D.; Zwerger, M.; Ryan, D.; Roberti, R.; Gaines, P. Lamin B receptor regulates the growth and maturation of myeloid progenitors via its sterol reductase domain: Implications for cholesterol biosynthesis in regulating myelopoiesis. J. Immunol. 2012, 188, 85-102. [CrossRef]

83. Bellezza, I.; Roberti, R.; Gatticchi, L.; Del Sordo, R.; Rambotti, M.G.; Marchetti, M.C.; Sidoni, A.; Minelli, A. A novel role for Tm7sf2 gene in regulating TNFalpha expression. PLoS ONE 2013, 8, e68017. [CrossRef] 
84. Bellezza, I.; Gatticchi, L.; del Sordo, R.; Peirce, M.J.; Sidoni, A.; Roberti, R.; Minelli, A. The loss of Tm7sf gene accelerates skin papilloma formation in mice. Sci. Rep. 2015, 5, 9471. [CrossRef] [PubMed]

85. Bartoli, D.; Piobbico, D.; Bellet, M.M.; Bennati, A.M.; Roberti, R.; Della Fazia, M.A.; Servillo, G. Impaired cell proliferation in regenerating liver of $3 \beta$-hydroxysterol $\Delta 14$-reductase (TM7SF2) knock-out mice. Cell Cycle 2016, 15, 2164-2173. [CrossRef] [PubMed]

86. Offiah, A.C.; Mansour, S.; Jeffrey, I.; Nash, R.; Whittock, N.; Pyper, R.; Bewley, S.; Clayton, P.T.; Hall, C.M. Greenberg dysplasia (HEM) and lethal X linked dominant Conradi-Hünermann chondrodysplasia punctata (CDPX2): Presentation of two cases with overlapping phenotype. J. Med. Genet. 2003, 40, e129. [CrossRef] [PubMed]

87. Greenberg, C.R.; Rimoin, D.L.; Gruber, H.E.; DeSa, D.J.; Reed, M.; Lachman, R.S. A new autosomal recessive lethal chondrodystrophy with congenital hydrops. Am. J. Med. Genet. 1988, 29, 623-632. [CrossRef] [PubMed]

88. Giorgio, E.; Sirchia, F.; Bosco, M.; Sobreira, N.L.M.; Baylor-Hopkins Center for Mendelian Genomics; Grosso, E.; Brussino, A.; Brusco, A. A novel case of Greenberg dysplasia and genotype-phenotype correlation analysis for LBR pathogenic variants: An instructive example of one gene-multiple phenotypes. Am. J. Med. Genet. A 2018. [CrossRef] [PubMed]

89. Gaudy-Marqueste, C.; Roll, P.; Esteves-Vieira, V.; Weiller, P.J.; Grob, J.J.; Cau, P.; Levy, N.; De Sandre-Giovannoli, A. LBR mutation and nuclear envelope defects in a patient affected with Reynolds syndrome. J. Med. Genet. 2010, 47, 361-370. [CrossRef]

90. Sukhanova, A.; Gorin, A.; Serebriiskii, I.G.; Gabitova, L.; Zheng, H.; Restifo, D.; Egleston, B.L.; Cunningham, D.; Bagnyukova, T.; Liu, H.; et al. Targeting C4-demethylating genes in the cholesterol pathway sensitizes cancer cells to EGF receptor inhibitors via increased EGF receptor degradation. Cancer Discov. 2013, 3, 96-111. [CrossRef]

91. He, M.; Smith, L.D.; Chang, R.; Li, X.; Vockley, J. The role of sterol-C4-methyl oxidase in epidermal biology. Biochim. Biophys. Acta 2014, 1841, 331-335. [CrossRef]

92. Mi, X.B.; Luo, M.X.; Guo, L.L.; Zhang, T.D.; Qiu, X.W. CHILD Syndrome: Case Report of a Chinese Patient and Literature Review of the NAD $[\mathrm{P}] \mathrm{H}$ Steroid Dehydrogenase-Like Protein Gene Mutation. Pediatr. Dermatol. 2015, 32, e277-e282. [CrossRef] [PubMed]

93. Seeger, M.A.; Paller, A.S. The role of abnormalities in the distal pathway of cholesterol synthesis in the Congenital Hemidysplasia with Ichthyosiform erythroderma and Limb Defects (CHILD) syndrome. Biochim. Biophys. Acta 2014, 1841, 345-352. [CrossRef]

94. Stottmann, R.W.; Turbe-Doan, A.; Tran, P.; Kratz, L.E.; Moran, J.L.; Kelley, R.I.; Beier, D.R. Cholesterol metabolism is required for intracellular hedgehog signal transduction in vivo. PLoS Genet. 2011, 7, e1002224. [CrossRef] [PubMed]

95. Cunningham, D.; DeBarber, A.E.; Bir, N.; Binkley, L.; Merkens, L.S.; Steiner, R.D.; Herman, G.E. Analysis of hedgehog signaling in cerebellar granule cell precursors in a conditional Nsdhl allele demonstrates an essential role for cholesterol in postnatal CNS development. Hum. Mol. Genet. 2015, 24, 2808-2825. [CrossRef] [PubMed]

96. Sato, R. Sterol metabolism and SREBP activation. Arch. Biochem. Biophys. 2010, 501, 177-181. [CrossRef] [PubMed]

97. Moss, G.P. Nomenclature of steroids (Recommendations 1989). Pure Appl. Chem. 1989, 61, $1783-1822$. [CrossRef]

98. Daum, G.; Lees, N.D.; Bard, M.; Dickson, R. Biochemistry, cell biology and molecular biology of lipids of Saccharomyces cerevisiae. Yeast 1998, 14, 1471-1510. [CrossRef]

99. Lees, N.D.; Bard, M.; Kirsch, D.R. Biochemistry and molecular biology of sterol synthesis in Saccharomyces cerevisiae. Crit. Rev. Biochem. Mol. Biol. 1999, 34, 33-47.

100. Li, L.; Kaplan, J. Characterization of yeast methyl sterol oxidase (ERG25) and identification of a human homologue. J. Biol. Chem. 1996, 271, 16927-16933. [CrossRef] [PubMed]

101. Bard, M.; Bruner, D.A.; Pierson, C.A.; Lees, N.D.; Biermann, B.; Frye, L.; Koegel, C.; Barbuch, R. Cloning and characterization of ERG25, the Saccharomyces cerevisiae gene encoding C-4 sterol methyl oxidase. Proc. Natl. Acad. Sci. USA 1996, 93, 186-190. [CrossRef] [PubMed]

102. Horinouchi, S.; Ishizuka, H.; Beppu, T. Cloning, nucleotide sequence, and transcriptional analysis of the $\mathrm{NAD}(\mathrm{P})$-dependent cholesterol dehydrogenase gene from a Nocardia sp. and its hyperexpression in Streptomyces spp. Appl. Environ. Microbiol. 1991, 57, 1386-1393. [PubMed] 
103. Gachotte, D.; Barbuch, R.; Gaylor, J.; Nickel, E.; Bard, M. Characterization of the Saccharomyces cerevisiae ERG26 gene encoding the C-3 sterol dehydrogenase (C-4 decarboxylase) involved in sterol biosynthesis. Proc. Natl. Acad. Sci. USA 1998, 95, 13794-13799. [CrossRef]

104. Aaron, K.E.; Pierson, C.A.; Lees, N.D.; Bard, M. The Candida albicans ERG26 gene encoding the C-3 sterol dehydrogenase (C-4 decarboxylase) is essential for growth. FEMS Yeast Res. 2001, 1, 93-101. [CrossRef] [PubMed]

105. Gachotte, D.; Sen, S.E.; Eckstein, J.; Barbuch, R.; Krieger, M.; Ray, B.D.; Bard, M. Characterization of the Saccharomyces cerevisiae ERG27 gene encoding the 3-keto reductase involved in C-4 sterol demethylation. Proc. Natl. Acad. Sci. USA 1999, 96, 12655-12660. [CrossRef] [PubMed]

106. Gachotte, D.; Eckstein, J.; Barbuch, R.; Hughes, T.; Roberts, C.; Bard, M. A novel gene conserved from yeast to humans is involved in sterol biosynthesis. J. Lipid Res. 2001, 42, 150-154. [PubMed]

107. Baudry, K.; Swain, E.; Rahier, A.; Germann, M.; Batta, A.; Rondet, S.; Mandala, S.; Henry, K.; Tint, G.S.; Edlind, T.; et al. The effect of the erg26-1 mutation on the regulation of lipid metabolism in Saccharomyces cerevisiae. J. Biol. Chem. 2001, 276, 12702-12711. [CrossRef] [PubMed]

108. Mo, C.; Valachovic, M.; Randall, S.K.; Nickels, J.T.; Bard, M. Protein-protein interactions among C-4 demethylation enzymes involved in yeast sterol biosynthesis. Proc. Natl. Acad. Sci. USA 2002, 99, 9739-9744. [CrossRef] [PubMed]

109. Ward, D.M.; Chen, O.S.; Li, L.; Kaplan, J.; Bhuiyan, S.A.; Natarajan, S.K.; Bard, M.; Cox, J.E. Altered sterol metabolism in budding yeast affects mitochondrial iron-sulfur (Fe-S) cluster synthesis. J. Biol. Chem. 2018, 293, 10782-10795. [CrossRef] [PubMed]

110. Gachotte, D.; Pierson, C.A.; Lees, N.D.; Barbuch, R.; Koegel, C.; Bard, M. A yeast sterol auxotroph (erg25) is rescued by addition of azole antifungals and reduced levels of heme. Proc. Natl. Acad. Sci. USA 1997, 94, 11173-11178. [CrossRef]

111. Wachtler, V.; Rajagopalan, S.; Balasubramanian, M.K. Sterol-rich plasma membrane domains in the fission yeast Schizosaccharomyces pombe. J. Cell Sci. 2003, 116, 867-874. [CrossRef]

112. Germann, M.; Gallo, C.; Donahue, T.; Shirzadi, R.; Stukey, J.; Lang, S.; Ruckenstuhl, C.; Oliaro-Bosso, S.; McDonough, V.; Turnowsky, F; et al. Characterizing sterol defect suppressors uncovers a novel transcriptional signaling pathway regulating zymosterol biosynthesis. J. Biol. Chem. 2005, 280, 35904-35913. [CrossRef]

113. Swain, E.; Baudry, K.; Stukey, J.; McDonough, V.; Germann, M.; Nickels, J.T., Jr. Sterol-dependent regulation of sphingolipid metabolism in Saccharomyces cerevisiae. J. Biol. Chem. 2002, 277, 26177-26184. [CrossRef]

114. Lv, J.M.; Hu, D.; Gao, H.; Kushiro, T.; Awakawa, T.; Chen, G.D.; Wang, C.X.; Abe, I.; Yao, X.S. Biosynthesis of helvolic acid and identification of an unusual C-4-demethylation process distinct from sterol biosynthesis. Nat. Commun. 2017, 8, 1644. [CrossRef] [PubMed]

115. Hughes, A.L.; Lee, C.Y.; Bien, C.M.; Espenshade, P.J. 4-Methyl sterols regulate fission yeast SREBP-Scap under low oxygen and cell stress. J. Biol. Chem. 2007, 282, 24388-24396. [CrossRef] [PubMed]

116. Rahier, A.; Smith, M.; Taton, M. The role of cytochrome b5 in $4 \alpha$-methyl-oxidation and C5(6) desaturation of plant sterol precursors. Biochem. Biophys. Res. Commun. 1997, 236, 434-437. [CrossRef] [PubMed]

117. Darnet, S.; Rahier, A. Plant sterol biosynthesis: Identification of two distinct families of sterol $4 \alpha$-methyl oxidases. Biochem. J. 2004, 378, 889-898. [CrossRef] [PubMed]

118. Darnet, S.; Bard, M.; Rahier, A. Functional identification of sterol- $4 \alpha$-methyl oxidase cDNAs from Arabidopsis thaliana by complementation of a yeast erg 25 mutant lacking sterol- $4 \alpha$-methyl oxidation. FEBS Lett. 2001, 508, 39-43. [CrossRef]

119. Sonawane, P.D.; Pollier, J.; Panda, S.; Szymanski, J.; Massalha, H.; Yona, M.; Unger, T.; Malitsky, S.; Arendt, P.; Pauwels, L.; et al. Plant cholesterol biosynthetic pathway overlaps with phytosterol metabolism. Nat. Plants 2016, 3, 16205. [CrossRef]

120. Rahier, A.; Darnet, S.; Bouvier, F.; Camara, B.; Bard, M. Molecular and enzymatic characterizations of novel bifunctional 3 $\beta$-hydroxysteroid dehydrogenases/C-4 decarboxylases from Arabidopsis thaliana. J. Biol. Chem. 2006, 281, 27264-27277. [CrossRef]

121. Lung, S.C.; Liao, P.; Yeung, E.C.; Hsiao, A.S.; Xue, Y.; Chye, M.L. Arabidopsis ACYL-COA-BINDING PROTEIN1 interacts with STEROL C4-METHYL OXIDASE1-2 to modulate gene expression of homeodomain-leucine zipper IV transcription factors. New Phytol. 2018, 218, 183-200. [CrossRef] 
122. Lung, S.C.; Liao, P.; Yeung, E.C.; Hsiao, A.S.; Xue, Y.; Chye, M.L. Acyl-CoA-Binding Protein ACBP1 Modulates Sterol Synthesis during Embryogenesis. Plant Physiol. 2017, 174, 1420-1435. [CrossRef]

123. Lange, I.; Poirier, B.C.; Herron, B.K.; Lange, B.M. Comprehensive Assessment of Transcriptional Regulation Facilitates Metabolic Engineering of Isoprenoid Accumulation in Arabidopsis. Plant Physiol. 2015, 169, 1595-1606. [CrossRef]

124. Burger, C.; Rondet, S.; Benveniste, P.; Schaller, H. Virus-induced silencing of sterol biosynthetic genes: Identification of a Nicotiana tabacum L. obtusifoliol-14 $\alpha$-demethylase (CYP51) by genetic manipulation of the sterol biosynthetic pathway in Nicotiana benthamiana L. J. Exp. Bot. 2003, 54, 1675-1683. [CrossRef] [PubMed]

125. Nakamoto, M.; Schmit, A.C.; Heintz, D.; Schaller, H.; Ohta, D. Diversification of sterol methyltransferase enzymes in plants and a role for beta-sitosterol in oriented cell plate formation and polarized growth. Plant J. 2015, 84, 860-874. [CrossRef] [PubMed]

126. Schaller, H.; Bouvier-Navé, P.; Benveniste, P. Overexpression of an Arabidopsis cDNA Encoding a Sterol-C241-Methyltransferase in Tobacco Modifies the Ratio of 24-Methyl Cholesterol to Sitosterol and Is Associated with Growth Reduction. Plant Physiol. 1998, 118, 461-469. [CrossRef] [PubMed]

127. Schaeffer, A.; Bronner, R.; Benveniste, P.; Schaller, H. The ratio of campesterol to sitosterol with modulates growth in Arabidopsis is controlled by STEROL METHYLTRANSFERASE 2-1. Plant J. 2001, 25, 605-615. [CrossRef] [PubMed]

128. Sharma, M.; Sasvari, Z.; Nagy, P.D. Inhibition of sterol biosynthesis reduces tombusvirus replication in yeast and plants. J. Virol. 2010, 84, 2270-2281. [CrossRef]

129. Kim, B.; Kim, G.; Fujioka, S.; Takatsuto, S.; Choe, S. Overexpression of 3beta-hydroxysteroid dehydrogenases/C-4 decarboxylases causes growth defects possibly due to abnormal auxin transport in Arabidopsis. Mol. Cells 2012, 34, 77-84. [CrossRef]

130. Simon-Plas, F.; Perraki, A.; Bayer, E.; Gerbeau-Pissot, P.; Mongrand, S. An update on plant membrane rafts. Curr. Opin. Plant Biol. 2011, 14, 642-649. [CrossRef]

131. Zhang, X.; Sun, S.; Nie, X.; Boutte, Y.; Grison, M.; Li, P.; Kuang, S.; Men, S. Sterol Methyl Oxidases Affect Embryo Development via Auxin-Associated Mechanisms. Plant Physiol. 2016, 171, 468-482. [CrossRef]

132. Klahre, U.; Noguchi, T.; Fujioka, S.; Takatsuto, S.; Yokota, T.; Nomura, T.; Yoshida, S.; Chua, N.H. The Arabidopsis DIMINUTO/DWARF1 gene encodes a protein involved in steroid synthesis. Plant Cell 1998, 10, 1677-1690. [CrossRef]

133. Choe, S.; Dilkes, B.P.; Fujioka, S.; Takatsuto, S.; Sakurai, A.; Feldmann, K.A. The DWF4 gene of Arabidopsis encodes a cytochrome P450 that mediates multiple $22 \alpha$-hydroxylation steps in brassinosteroid biosynthesis. Plant Cell 1998, 10, 231.

134. Choe, S.W.; Noguchi, T.; Fujioka, S.; Takatsuto, S.; Tissier, C.P.; Gregory, B.D.; Ross, A.S.; Tanaka, A.; Yoshida, S.; Tax, F.E.; et al. The Arabidopsis dwf7/ste1 mutant is defective in the $\Delta 7$ sterol C-5 desaturation step leading to brassinosteroid biosynthesis. Plant Cell 1999, 11, 207-221. [PubMed]

135. Choe, S.; Dilkes, B.P.; Gregory, B.D.; Ross, A.S.; Yuan, H.; Noguchi, T.; Fujioka, S.; Takatsuto, S.; Tanaka, A.; Yoshida, S.; et al. The Arabidopsis dwarf1 mutant is defective in the conversion of 24-methylenecholesterol to campesterol in brassinosteroid biosynthesis. Plant Physiol. 1999, 119, 897-907. [CrossRef]

136. Silvestro, D.; Andersen, T.G.; Schaller, H.; Jensen, P.E. Plant Sterol Metabolism. $\Delta 7-S t e r o l-C 5-D e s a t u r a s e$ (STE1/DWARF7), $\Delta 5,7-$ Sterol- $\Delta$ 7-Reductase (DWARF5) and $\Delta$ 24-Sterol- $\Delta$ 24-Reductase (DIMINUTO/DWARF1) Show Multiple Subcellular Localizations in Arabidopsis thaliana (Heynh) L. PLoS ONE 2013, 8, e56429. [CrossRef] [PubMed]

137. Willemsen, V.; Friml, J.; Grebe, M.; van den Toorn, A.; Palme, K.; Scheres, B. Cell polarity and PIN protein positioning in Arabidopsis require STEROL METHYLTRANSFERASE1 function. Plant Cell 2003, 15, 612-625. [CrossRef] [PubMed]

138. Men, S.; Boutte, Y.; Ikeda, Y.; Li, X.; Palme, K.; Stierhof, Y.D.; Hartmann, M.A.; Moritz, T.; Grebe, M. Sterol-dependent endocytosis mediates post-cytokinetic acquisition of PIN2 auxin efflux carrier polarity. Nat. Cell Biol. 2008, 10, 237-244. [CrossRef]

139. Butcher, R.A. Small-molecule pheromones and hormones controlling nematode development. Nat. Chem. Biol. 2017, 13, 577-586. [CrossRef] [PubMed]

140. Matyash, V.; Entchev, E.V.; Mende, F.; Wilsch-Brauninger, M.; Thiele, C.; Schmidt, A.W.; Knolker, H.J.; Ward, S.; Kurzchalia, T.V. Sterol-derived hormone(s) controls entry into diapause in Caenorhabditis elegans by consecutive activation of DAF-12 and DAF-16. PLoS Biol. 2004, 2, e280. [CrossRef] 
141. Lee, A.K.; Banta, A.B.; Wei, J.H.; Kiemle, D.J.; Feng, J.; Giner, J.L.; Welander, P.V. C-4 sterol demethylation enzymes distinguish bacterial and eukaryotic sterol synthesis. Proc. Natl. Acad. Sci. USA 2018, 115, 5884-5889. [CrossRef]

142. Wollam, J.; Magomedova, L.; Magner, D.B.; Shen, Y.; Rottiers, V.; Motola, D.L.; Mangelsdorf, D.J.; Cummins, C.L.; Antebi, A. The Rieske oxygenase DAF-36 functions as a cholesterol 7-desaturase in steroidogenic pathways governing longevity. Aging Cell 2011, 10, 879-884. [CrossRef]

143. Poklepovich, T.J.; Urtasun, N.; Miranda, M.V.; Nusblat, A.D.; Nudel, C.B. Expression and functional characterization of a C-7 cholesterol desaturase from Tetrahymena thermophila in an insect cell line. Steroids 2015, 96, 132-139. [CrossRef]

144. Najle, S.R.; Nusblat, A.D.; Nudel, C.B.; Uttaro, A.D. The Sterol-C7 desaturase from the ciliate Tetrahymena thermophila is a Rieske Oxygenase, which is highly conserved in animals. Mol. Biol. Evol. 2013, 30, 1630-1643. [CrossRef] [PubMed]

145. Odds, F.C.; Brown, A.J.P.; Gow, N.A.R. Antifungal agents: Mechanisms of action. Trends Microbiol. 2003, 11, 272-279. [CrossRef]

146. Warrilow, A.G.; Parker, J.E.; Kelly, D.E.; Kelly, S.L. Azole affinity of sterol 14 $\alpha$-demethylase (CYP51) enzymes from Candida albicans and Homo sapiens. Antimicrob. Agents Chemother. 2013, 57, 1352-1360. [CrossRef] [PubMed]

147. Muller, C.; Binder, U.; Bracher, F.; Giera, M. Antifungal drug testing by combining minimal inhibitory concentration testing with target identification by gas chromatography-mass spectrometry. Nat. Protoc. 2017, 12, 947-963. [CrossRef] [PubMed]

148. Jachak, G.R.; Ramesh, R.; Sant, D.G.; Jorwekar, S.U.; Jadhav, M.R.; Tupe, S.G.; Deshpande, M.V.; Reddy, D.S. Silicon Incorporated Morpholine Antifungals: Design, Synthesis, and Biological Evaluation. ACS Med. Chem. Lett. 2015, 6, 1111-1116. [CrossRef] [PubMed]

149. Kuchta, T.; Bartkova, K.; Kubinec, R. Ergosterol depletion and 4-methyl sterols accumulation in the yeast Saccharomyces cerevisiae treated with an antifungal, 6-amino-2-n-pentylthiobenzothiazole. Biochem. Biophys. Res. Commun. 1992, 189, 85-91. [CrossRef]

150. Kuchta, T.; Leka, C.; Farkas, P.; Bujdakova, H.; Belajova, E.; Russell, N.J. Inhibition of sterol 4-demethylation in Candida albicans by 6-amino-2-n-pentylthiobenzothiazole, a novel mechanism of action for an antifungal agent. Antimicrob. Agents Chemother. 1995, 39, 1538-1541. [CrossRef] [PubMed]

151. Fabry, S.; Gaborova, S.; Bujdakova, H.; Klobusicky, M.; Vollekova, A.; Kuchta, T. Inhibition of germ tube formation, filamentation and ergosterol biosynthesis in Candida albicans treated with 6-amino-2-n-pentylthiobenzothiazole. Folia Microbiol. (Praha) 1999, 44, 523-526. [CrossRef]

152. Darnet, S.; Rahier, A. Enzymological properties of sterol-C4-methyl-oxidase of yeast sterol biosynthesis. Biochim. Biophys. Acta 2003, 1633, 106-117. [CrossRef]

153. Nose, H.; Fushimi, H.; Seki, A.; Sasaki, T.; Watabe, H.; Hoshiko, S. PF1163A, a Novel Antifungal Agent, Inhibit Ergosterol Biosynthesis at C-4 Sterol Methyl Oxidase. J. Antibiot. 2002, 55, 969-974. [CrossRef]

154. Ekhato, I.V.; Robinson, C.H. Synthesis of New Nitro and Amino Sterols-Potential Inhibitors of 4-Methyl Sterol Oxidase. J. Chem. Soc.-Perkin Trans. 1 1988, 3239-3242. [CrossRef]

155. Ekhato, I.V.; Robinson, C.H. Synthesis of Novel $4 \alpha$-Substituted Sterols. J. Org. Chem. 1989, 54, $1327-1331$. [CrossRef]

156. Singh, D.K.; Porter, T.D. Inhibition of sterol $4 \alpha$-methyl oxidase is the principal mechanism by which garlic decreases cholesterol synthesis. J. Nutr. 2006, 136, 759s-764s. [CrossRef]

157. Lindenthal, B.; Holleran, A.L.; Aldaghlas, T.A.; Ruan, B.; Schroepfer, G.J., Jr.; Wilson, W.K.; Kelleher, J.K. Progestins block cholesterol synthesis to produce meiosis-activating sterols. FASEB J. 2001, 15, 775-784. [CrossRef] [PubMed]

158. Hashimoto, F.; Hayashi, H. Identification of intermediates after inhibition of cholesterol synthesis by aminotriazole treatment in vivo. Biochim. Biophys. Acta 1991, 1086, 115-124. [CrossRef]

159. Hashimoto, F.; Hayashi, H. Peroxisomal cholesterol synthesis in vivo: Accumulation of 4-methyl intermediate sterols after aminotriazole inhibition of cholesterol synthesis. Biochim. Biophys. Acta 1994, 1214, 11-19. [CrossRef]

160. Helliwell, S.B.; Karkare, S.; Bergdoll, M.; Rahier, A.; Leighton-Davis, J.R.; Fioretto, C.; Aust, T.; Filipuzzi, I.; Frederiksen, M.; Gounarides, J.; et al. FR171456 is a specific inhibitor of mammalian NSDHL and yeast Erg26p. Nat. Commun. 2015, 6, 8613. [CrossRef] [PubMed] 
161. Debieu, D.; Bach, J.; Hugon, M.; Malosse, C.; Leroux, P. The hydroxyanilide fenhexamid, a new sterol biosynthesis inhibitor fungicide efficient against the plant pathogenic fungus Botryotinia fuckeliana (Botrytis cinerea). Pest Manag. Sci. 2001, 57, 1060-1067. [CrossRef]

162. Trzaskos, J.M.; Fischer, R.T.; Favata, M.F. Mechanistic studies of lanosterol C-32 demethylation. Conditions which promote oxysterol intermediate accumulation during the demethylation process. J. Biol. Chem. 1986, 261, 16937-16942. [PubMed]

163. Ori, K.; Koroda, M.; Mimaki, Y.; Sakagami, H.; Sashida, Y. Lanosterol and tetranorlanosterol glycosides from the bulbs of Muscari paradoxum. Phytochemistry 2003, 64, 1351-1359. [CrossRef]

164. Ragasa, C.Y.; Tiu, F.; Rideout, J.A. New cycloartenol esters from Ixora coccinea. Nat. Prod. Res. 2004, 18, 319-323. [CrossRef] [PubMed]

165. Gallo, C.; d'Ippolito, G.; Nuzzo, G.; Sardo, A.; Fontana, A. Autoinhibitory sterol sulfates mediate programmed cell death in a bloom-forming marine diatom. Nat. Commun. 2017, 8, 1292. [CrossRef] [PubMed]

166. Massé, R.; Huang, Y.S.; Eid, K.; Laliberté, C.; Davignon, J. Plasma methyl sterol sulfates in familial hypercholesterolemia after partial ileal bypass. Can. J. Biochem. 1982, 60, 556-563. [CrossRef] [PubMed]

167. Hu, X.; Wang, Y.; Hao, L.Y.; Liu, X.; Lesch, C.A.; Sanchez, B.M.; Wendling, J.M.; Morgan, R.W.; Aicher, T.D.; Carter, L.L.; et al. Sterol metabolism controls $\mathrm{T}(\mathrm{H}) 17$ differentiation by generating endogenous RORgamma agonists. Nat. Chem. Biol. 2015, 11, 141-147. [CrossRef] [PubMed]

(C) 2019 by the authors. Licensee MDPI, Basel, Switzerland. This article is an open access article distributed under the terms and conditions of the Creative Commons Attribution (CC BY) license (http://creativecommons.org/licenses/by/4.0/). 